28 Research Square

\title{
A Survey on some of the Global Effects of the COVID-19 Pandemic
}

Ishaani Priyadarshini ( $\square$ ishaani@udel.edu )

Research

Keywords: COVID-19, Coronavirus, Pandemic, Gross Domestic Product (GDP), Global Effects

Posted Date: April 7th, 2020

DOI: https://doi.org/10.21203/rs.3.rs-20842/v1

License: (1) (i) This work is licensed under a Creative Commons Attribution 4.0 International License. Read Full License 


\title{
A Survey on some of the Global Effects of the COVID-19 Pandemic
}

Ishaani Priyadarshini*, Department of Electrical and Computer Science, University of Delaware, Newark, Delaware, USA, ishaani@udel.edu

\begin{abstract}
Ever since COVID-19 was first identified in Wuhan, China in December 2019, it has gained a lot of popularity. Within a span of two months, it managed to travel across the globe and affected more than a million people, resulting in several deaths. The World Health Organization recently declared COVID-19 as a pandemic over the number of cases registered by country. However, there is a lot more to just people being infected by the disease. Apparently COVID-19 has managed to disrupt businesses all over the world causing world panic. In this paper, some global effects of the COVID-19 pandemic are identified and certain trends related to the same over the approximate time period of January 2020- March 2020 have been observed. The impacts of the COVID-19 outbreak on the global Gross Domestic Product (GDP), the travel and tourism industry and high tech product shipments have been analyzed. The study would assist the industries to prepare better for the global crisis and would assist them in contemplating specific scenarios in case of an epidemic or pandemic in the future.
\end{abstract}

Keywords: COVID-19, Coronavirus, Pandemic, Gross Domestic Product (GDP), Global Effects

\section{Introduction}

Coronaviruses are a large family of viruses that are capable of causing illness in animals and humans, thus affecting many living species. Some coronaviruses that are known to affect humans are Middle East Respiratory Syndrome (MERS) and Severe Acute Respiratory Syndrome (SARS) (Guarner,2020). COVID-19 is the most recently discovered coronavirus. The 2019 novel coronavirus or COVID-19 is a virus strain, which was first identified in Wuhan, Hubei Province, China in December 2019 (Novel, 2020). Ever since its identification, it has managed to spread across the globe and infect more than a million people across various continents. Since it is zoonotic, many people attribute their origin to be mammals like bats (Zhou et. al, 2020). Several others attribute the COVID-19 outbreak to the seafood market in China (Jiang et al, 2020).

Since its identification, in December 2019, COVID-19 has managed to spread across the globe and cause several deaths, which led the World Health Organization (WHO) to declare it a pandemic (Gates, 2020). Given the fact that the pandemic has been spreading across the globe rampantly, within two months it has affected a million people over more than 80 countries with a mortality rate of $3.4 \%$. Some of the countries that have been affected the most are China, South Korea, Italy, and Iran (Porcheddu et al, 2020; MacIntyre, 2020). The increasing number of confirmed cases led to the closing down of several businesses in China and also resulted in locking down Italy. And the number of cases keeps on increasing on a daily basis. What makes COVID-19 outrageous is that it can spread before it produces standard symptoms like the common cold and several days after recovery. With the incubation period being more than five days, it is hard to tell if a patient is suffering from COVID-19 or not. This has led to an increase in the number of cases over the last couple of months. What makes the situation even worse, is that there is no vaccine for treating COVID-19 as of yet. Therefore, with the increasing number of people who are infected with the pandemic, several businesses are also affected. Industries like the airline, tourism, retail, etc may witness the effect of the coronavirus outbreak (Habibi et, al, 2020; Allam and Jones, 2020). Due to globalization, several other industries may also be affected thus leading to an overall global effect. Since COVID-19 has been spreading like forest fires and may continue doing so before its vaccine is finally developed, it is 
important to anticipate what global impacts it may have and what all industries might be affected by its spreading. This paper presents how COVID-19 has spread across the globe as well as the various industries it affects like travel, tourism, shipment, etc by plotting trends for existing data. Further, trends to analyze the Gross Domestic Product (GDP) growth and the Gross Domestic Product (GDP) loss due to the pandemic have also been presented.

The rest of the paper is organized as follows. Section 2 lists the related works that have been done in the past related to COVID-19. In Section 3 the economic sectors that are believed to be the most affected by the pandemic have been presented. Section 4 takes into account the Experimental Analysis, while Section 5, highlights the Results and Findings. In section 6, Conclusion and Future Work are reported.

\section{Related Work}

In this section, some of the research works that have been done in the past for COVID-19 are presented. This is followed by a critical evaluation of the existing works so as to highlight the novelty of the proposed research work.

(Chinnazi et al, 2020) presented research on the effect of travel restrictions on the spread of the COVID-19 outbreak. A global metapopulation disease transmission model has been taken into account for depicting the impact of travel limitations nationally as well as internationally. Since the cases have been listed from 23 January 2020, most Chinese cities might have already received several infected travelers. Modeling results also depict that sustained $90 \%$ travel restrictions to and from Mainland China only modestly affect the epidemic trajectory unless combined with a $50 \%$ or higher reduction of transmission in the community. Based on the research it is expected that travel restrictions to COVID-19 affected areas will have modest effects. Moreover, transmission-reduction interventions may also assist in mitigating the epidemic.

(Qi et. al, 2020) conducted a large scale survey of the psychological distress among Chinese people due to the COVID-19 epidemic. The psychological distress may be attributed to the unprecedented strict quarantine measures in China. Due to this, a large number of people have been kept in isolation this has affected several aspects of their lives. Moreover, it has also triggered a wide variety of psychological problems, such as panic disorder, anxiety, and depression. The study provides certain recommendations for improving the mental situation of the patients. Some of the recommendations are paying more attention to vulnerable groups like the young, the elderly, women and migrant workers, and easy accessibility of medical resources and the public health service system for the patients. Nationwide strategic planning and coordination for psychological first aid during major disasters may possibly be established and a comprehensive crisis prevention system that incorporates monitoring, screening, etc could be built to reduce psychological distress and prevent further mental health problems.

(Heymann and Shindo, 2020) laid out some mitigation strategies in case COVID-19 affects a wider community. Close monitoring, continued evolution of communication strategies, intensive control for isolated patients and containment activities could be a few ways to ensure public health. Intensified active surveillance, preparation for the resilience of health systems and mitigation activities may also contribute to public health. Serological tests and continuous research are also necessary to prevent the pandemic.

(Gilbert et. al, 2020) performed a study to analyze the vulnerability of African countries against importations of COVID-19. The study was conducted by taking into account the volume of air travel departing from airports in the infected provinces in China and directed to Africa to estimate the risk of importation per country. Preparedness and Vulnerability of the country were used as indicators to detect the vulnerability of the countries (WHO International Health Regulations Monitoring and Evaluation 
Framework and Infectious Disease Vulnerability Index). It was found that Egypt, Algeria, and South Africa are the countries with the highest importation risk and they have moderate to high capacity to respond to outbreaks. Countries at moderate risk are Nigeria, Ethiopia, Sudan, Angola, Tanzania, Ghana, and Kenya. They have variable capacity and high vulnerability.

(Wong et. al, 2020) listed seven critical issues for the COVID-19 outbreak in Singapore that require coordinated attention and action. Better understanding regarding the modes of transmission, detailed travel and exposure history of the epidemic and identification of individuals who are at greater risk of the infection are some issues. Further, information on the effectiveness of agents and better communication ways may also be helpful. Healthcare professionals who care for COVID-19 patients could be under enormous stress, and therefore it must be taken into consideration. The development of an effective vaccine would definitely prevent the rampant spreading of the disease.

(Columbus et. al 2020) label COVID-19 as an emerging global threat in their study. The research provides a timeline of the epidemic and lists the number of cases confirmed, recovered and cases that resulted in the death of the patient. The clinical features of COVID-19 have also been mentioned in the article. It is suggested that diagnosis be performed by the RT-PCR analysis of upper respiratory, lower respiratory and serum samples. For infection control, a high level of vigilance and timely consultation are required. Patients must undergo isolations as part of the treatment. There are several unresolved issues pertaining to information regarding the virology, epidemiology, and transmission of COVID-19.

(Sun et. al, 2020) presented a study on COVID-19 based on current evidence. The study details that the source of SARS-CoV-2 and COVID-19 are related since both are zoonotic. The study also presents the epidemiological characteristics of COVID-19 related to incubation rate and fatality rate. The mechanism, symptoms, and diagnosis of COVID-19 have been mentioned along with the prevention and treatment. The study also mentions that pulmonary fibrosis may be one of the severe complications after patients recover from COVID-2019.

(Mustapha et. al, 2020) suggested some public health preparedness for the COVID-19 outbreak in Nigeria. Nigeria appears to be equipped with the technical and human resources required to diagnose COVID-19. A Surveillance and Outbreak Response Management System has been developed to treat patients diagnosed with COVID-19.

(Koh, 2020) presented a study on the occupational risks of the COVID-19. Since it is contagious, several occupational groups are at risk of being infected. Some groups that have been infected are domestic workers, tour guides, taxi drivers, casino workers, etc. These workers may be staff in the tourism, retail, and hospitality industry, transport and security workers, and construction industry. The crew on ships, healthcare professionals, ambulance drivers, etc. are also at the risk of getting infected.

(Gallego et. al, 2020) performed a study on the COVID-19 outbreak and its implications on the Tokyo 2020 Summer Olympic Games. Japan is believed to be the third most affected country after China and South Korea. It is expected that Tokyo will receive 20 million visitors (non-residents), to be attended by 70,000 volunteers of the games and 8000 for the city. 11,090 Olympic athletes would be participating in the event Also there will be 14 million food dishes to be served to the participants. All these conditions pose a major challenge for organizers, especially considering health security. Moreover, the relative position of the Yokohama port, where the cruise ship Diamond Princess is docked is very close to the venue of the Olympic Games. 
Table 1: Summarized Critical Evaluation of prior works

\begin{tabular}{|c|c|c|c|}
\hline Year and Author & Research & $\begin{array}{l}\text { Methodology/ } \\
\text { Parameters }\end{array}$ & Limitations \\
\hline Chinnazi et. al, 2020 & $\begin{array}{l}\text { Research on the effect } \\
\text { of travel restrictions on } \\
\text { the spread of the } \\
\text { COVID-19 outbreak }\end{array}$ & $\begin{array}{l}\text { Global metapopulation } \\
\text { disease } \\
\text { model }\end{array}$ & $\begin{array}{l}\text { Cases have been listed } \\
\text { from } 23 \text { January } 2020 \text {, } \\
\text { so it is possible that a } \\
\text { lot of Chinese cities } \\
\text { might have already } \\
\text { been infected by then. } \\
\text { The research takes into } \\
\text { account travel } \\
\text { restrictions to and fro } \\
\text { Mainland China, while } \\
\text { COVID-19 is a global } \\
\text { pandemic. }\end{array}$ \\
\hline Qi et. al, 2020 & $\begin{array}{l}\text { Large scale survey of } \\
\text { the psychological } \\
\text { distress among Chinese } \\
\text { people due to the } \\
\text { COVID-19 epidemic }\end{array}$ & $\begin{array}{l}\text { Self-reporting } \\
\text { questionnaire } \\
\text { several and } \\
\text { related to demographic } \\
\text { data (ie, province, } \\
\text { gender, age, education, } \\
\text { and occupation), } \\
\text { frequency of anxiety, } \\
\text { depression, specific } \\
\text { phobias, cognitive } \\
\text { change, avoidance and } \\
\text { compulsive behavior, } \\
\text { physical symptoms, and } \\
\text { loss of social } \\
\text { functioning in the past } \\
\text { week. }\end{array}$ & $\begin{array}{l}\text { While the research is a } \\
\text { large scale survey, due } \\
\text { to the lack of empirical } \\
\text { data (trends and } \\
\text { graphs), it is difficult to } \\
\text { anticipate the overall } \\
\text { results. Further, the } \\
\text { study was restricted to } \\
\text { only China and has data } \\
\text { up to } 10 \text { February } 2020 .\end{array}$ \\
\hline $\begin{array}{l}\text { Heymann and Shindo, } \\
2020\end{array}$ & $\begin{array}{l}\text { Proposed some } \\
\text { mitigation strategies for } \\
\text { COVID-19 }\end{array}$ & $\begin{array}{l}\text { Close monitoring } \\
\text { continued evolution of } \\
\text { communication } \\
\text { strategies, intensive } \\
\text { control for isolated } \\
\text { patients, containment } \\
\text { activities, etc. }\end{array}$ & $\begin{array}{l}\text { There is no justification } \\
\text { or experimental } \\
\text { analysis of how the } \\
\text { proposed } \\
\text { methodologies might } \\
\text { actually be effective. }\end{array}$ \\
\hline Gilbert et. al, 2020 & $\begin{array}{l}\text { Study to analyze the } \\
\text { vulnerability of African } \\
\text { countries against } \\
\text { importations } \\
\text { COVID-19. }\end{array}$ & $\begin{array}{l}\text { WHO International } \\
\text { Health Regulations } \\
\text { Monitoring and } \\
\text { Evaluation Framework } \\
\text { and Infectious Disease } \\
\text { Vulnerability Index }\end{array}$ & $\begin{array}{l}\text { Only three airports have } \\
\text { been taken into } \\
\text { consideration. } \\
\text { Moreover, Hubei, } \\
\text { where COVID-19 was } \\
\text { first identified, has not } \\
\text { been taken into } \\
\text { consideration. }\end{array}$ \\
\hline
\end{tabular}




\begin{tabular}{|c|c|c|c|}
\hline Wong et. al, 2020 & $\begin{array}{l}\text { Listed seven critical } \\
\text { issues for the } \\
\text { COVID-19 outbreak in } \\
\text { Singapore }\end{array}$ & $\begin{array}{l}\text { A better understanding } \\
\text { of the modes of } \\
\text { transmission, detailed } \\
\text { travel and exposure } \\
\text { history of the epidemic } \\
\text { and identification of } \\
\text { individuals who are at } \\
\text { greater risk of the } \\
\text { infection, etc. }\end{array}$ & $\begin{array}{l}\text { The study is confined to } \\
\text { Singapore while } \\
\text { COVID-19 is a global } \\
\text { epidemic and similar } \\
\text { issues are present } \\
\text { globally. }\end{array}$ \\
\hline Columbus et. al 2020 & $\begin{array}{l}\text { Study on COVID-19 } \\
\text { outbreak }\end{array}$ & $\begin{array}{l}\text { Timeline of the } \\
\text { epidemic, clinical } \\
\text { features, diagnosis, } \\
\text { infection control, etc. }\end{array}$ & $\begin{array}{l}\text { The study does not } \\
\text { perform any } \\
\text { experimental analysis } \\
\text { or present the findings } \\
\text { in the form of graphs or } \\
\text { trends. } \\
\text { Moreover, the } \\
\text { pandemic is listed as a } \\
\text { global threat, but the } \\
\text { article does not mention } \\
\text { anything about the } \\
\text { global issues caused } \\
\text { due to COVID-19 }\end{array}$ \\
\hline Sun et. al, 2020 & $\begin{array}{l}\text { Study on COVID-19 } \\
\text { based on current } \\
\text { evidence }\end{array}$ & $\begin{array}{l}\text { Epidemiological } \\
\text { characteristics, } \\
\text { mechanism, symptoms, } \\
\text { diagnosis prevention, } \\
\text { treatment }\end{array}$ & $\begin{array}{l}\text { The study does not take } \\
\text { into account any } \\
\text { empirical study or } \\
\text { experimental analysis. }\end{array}$ \\
\hline Mustapha et. al, 2020 & $\begin{array}{l}\text { Public health } \\
\text { preparedness for the } \\
\text { COVID-19 outbreak in } \\
\text { Nigeria }\end{array}$ & $\begin{array}{l}\text { Surveillance and } \\
\text { Outbreak Response } \\
\text { Management System, } \\
\text { sufficient technical and } \\
\text { human resources }\end{array}$ & $\begin{array}{l}\text { The study is confined to } \\
\text { Nigeria although } \\
\text { COVID-19 is a global } \\
\text { pandemic. } \\
\text { The study lack } \\
\text { empirical study and } \\
\text { experimental .analysis }\end{array}$ \\
\hline Koh, 2020 & $\begin{array}{l}\text { Study on the } \\
\text { occupational risks of } \\
\text { the COVID-19 }\end{array}$ & $\begin{array}{l}\text { Observed } 25 \text { locally } \\
\text { transmitted cases in } \\
\text { Singapore }\end{array}$ & $\begin{array}{l}\text { Cases confirmed are } \\
\text { confined to Singapore } \\
\text { while COVID-19 is a } \\
\text { global epidemic. }\end{array}$ \\
\hline Gallego et. al, 2020 & $\begin{array}{l}\text { Implications of } \\
\text { COVID-19 on Tokyo } \\
2020 \text { Summer Olympic } \\
\text { Games }\end{array}$ & $\begin{array}{l}\text { Anticipating the } \\
\text { number of people who } \\
\text { will be attending the } \\
\text { event, } \\
\text { The location from } \\
\text { Yokohama port to the } \\
\text { venues of the game }\end{array}$ & $\begin{array}{l}\text { The study does not } \\
\text { feature any graph plots } \\
\text { or trends (empirical } \\
\text { study or experimental } \\
\text { analysis) }\end{array}$ \\
\hline
\end{tabular}


In this section, some of the prior work that has been done with respect to the COVID-19 outbreak has been listed. A critical analysis of the existing works was also presented so as to highlight the contribution of the proposed research work with respect to the already existing works. Some observations based on the related work as follows

1. Many research papers discuss the overall analysis of the COVID-19 outbreak and suggested several critical measures that could be taken into account for controlling its spread. While its implications on psychology as well as events like the Olympic Games were highlighted, the overall implication or global effects were not taken into consideration. Detailed research about the global effects of COVID-19 has been presented for the first time in the proposed research work.

2. Three important economy sectors i.e. Gross Domestic Product (GPD), Travel and Tourism Industry and High Tech Products shipment have been considered for the research.

3. Several research papers are similar to reports since they lack any experimental analysis or empirical study. In this paper, the global effects of the COVID-19 outbreak have been justified using several graphs.

4. The COVID-19 outbreak has been analyzed specific to locations like Japan, Nigeria, Singapore, etc. in the past. This research takes into account the effects of COVID-19 on a global scale.

5. The dataset used in this paper the latest and has more data, which gives a better analysis of the COVID-19 outbreak (January 22, 2020, to March 12, 2020)

\section{Proposed Work}

Since its identification in December 2019, COVID-19 has spread across the globe very quickly and has affected several continents. While the number of confirmed cases keeps on increasing, the pandemic has also vandalized other several industries. In this section, three sectors of the economy that are believed to have been affected due to the outbreak are taken into consideration. They are as follows:

1. Gross Domestic Product: The Gross Domestic Product is used to measure the value of economic activity within a country. It may be defined as the sum of the market values, or prices, of all final goods and services produced in an economy during a period of time. GDP may have several components to it. It may also be expressed as a number that explains the worth of the output of a country in local currency. It is one of the most common indicators for tracking the health of a nation's economy. Economists use GDP to determine whether an economy is growing or experiencing a recession. COVID-19 may have an impact on the global economy in three main ways:

a. Direct impact on production: With the outbreak of COVID-19, Hubei province and other areas have been shut down which has an effect on the Chinese production of goods. Due to globalization, many countries may also have a direct impact. The slowdown in China has effects on exporters to China. China has exporters all over the world. Therefore even without any new outbreaks of the disease, these countries might experience slow growth in the first half of 2020.

b. Supply chain and market disruption: China is the production hub for many goods and several manufacturing firms all over the world rely on imported goods from China and other countries that have been affected by the COVID-19 outbreak. Sales in China also have an impact on the financial goals of several firms. With the economic activities and transportation restrictions, several firms and countries will be affected in terms of the production and profitability of manufacturing goods and raw materials. Companies that rely on intermediate goods may not be able to switch sourcing and may ultimately have to depend on 
the fading of the outbreak. This will slow down the production process and companies will suffer huge losses. Small and medium-sized firms may find it even more difficult to survive. Businesses tied to travel and tourism industries have been worst affected and may not recover anytime soon.

c. The financial impact on firms and financial markets: Disruptions in the production of goods may be stressful for firms with inadequate liquidity. It may be difficult for traders to comprehend the firms that might be vulnerable. The resulting rise in risk may also lead to financial market players taking investment positions that are unprofitable under current conditions. This would definitely weaken trust in financial instruments and markets. As participants become more concerned about counterparty risk, there could be financial market disruption. There may also be a decline in equity markets and corporate bond markets due to the uncertainty created by the pandemic. Compared to SARS, COVID-19 has a much lower mortality rate, but it is more contagious. Hence, there is still a great deal of uncertainty about COVID-19.

2. Global Travel and Tourism Industry: The COVID-19 outbreak has been a major jolt to the travel and tourism industry. Travel and tourism are huge global businesses that contribute to the global Gross Domestic Product (GDP) as well as global employment. The impact on travel to and from China may have devastating effects on the global economy. Many Airlines, have canceled several flights or significantly reduced the number of flights in and out of China. Many countries closed their land borders, cross-border ferries, and railways to and from China. The crisis is severe in Europe too. Since the outbreak, Italy, popular tourist destinations like Venice and Milan are deserted. Public places like museums and theaters closed, while major events got canceled. The tourism industry may witness empty hotels, canceled flights, closed tourist sights. Asian countries like Indonesia, Japan, Thailand, South Korea, Singapore, Malaysia, Cambodia and Vietnam that are popular tourist attractions may also suffer. The fallout has also led to industries tied with airlines, hotels, casinos, tourism offices and booking agencies scrambling. Smaller businesses like souvenir shops, hotels, and tour operators may have to close down. An increase in domestic and international travel restrictions, as well as increasing apprehension from travelers, could mean a significant decline in global tourism if the spread of the virus continues to exacerbate. The global coronavirus outbreak may put millions of travel and tourism jobs are at risk. Even Cruise ship firm Princess Cruises may suspend all operations for a given period of time. Governments may have to take several steps to protect the industry. Simplifying visas, reducing costs, promoting travel destinations, etc. may be considered for strengthening the travel and tourism industry.

3. High Tech Products: With the largest concentration of electronics products assembled in China, the COVID-19 outbreak creates huge problems for the entire tech industry, which ultimately has global effects. Basic semiconductors and printed circuit boards (PCBs) to complete working systems like smartphones and laptops could be impacted by the pandemic. Cars and industrial applications may also be negatively impacted. Since China is the epicenter of technology manufacturing, the COVID-19 outbreak could have a devastating effect on the global smartphone market. Factory closures and delays in production might be there for an unknown period of time. Production issues may also lead to replacement and servicing issues. There might be a drop in shipments. If the coronavirus outbreak situation worsens, many Chinese brands may face the same situation. Some companies may have to rely on overseas operations. As COVID-19 spreads to other manufacturing centers, non-Chinese companies must take preventative measures. 
Electronic goods might need to be produced at different locations for supply if the situation does not improve.

\section{Experimental Analysis}

In the previous section, some economical sectors that might be affected due to the COVID-19 outbreak were considered. It included Gross Domestic Product (GDP), the travel and tourism industry and high tech products that are needed all over the world. In order to justify the proposed claim, that the COVID-19 outbreak has an impact on these economic sectors, several graphs, and trends have been presented in the Results section. This section highlights the data gathered and what all trends are necessary to be presented for the research.

\subsection{Datasets}

The datasets have been taken from The Humanitarian Data Exchange. The datasets incorporate Novel CoronaVirus (COVID-19) epidemiological data since 22 January 2020. The data has been analyzed from 22 January 2020 to 12 March 2020. The data is compiled by the Johns Hopkins University Center for Systems Science and Engineering (JHU CCSE). The various sources of this data have been taken from the World Health Organization (WHO), DXY.cn. Pneumonia. 2020, BNO News, National Health Commission of the People's Republic of China (NHC), China CDC (CCDC), Hong Kong Department of Health, Macau Government, Taiwan CDC, US CDC, Government of Canada, Australia Government Department of Health, European Centre for Disease Prevention and Control (ECDC), Ministry of Health Singapore (MOH). JSU CCSE also maintains this data on the 2019 Novel Coronavirus COVID-19 (2019-nCoV) Data Repository on Github. Three datasets have been made available, which include fields Province/State, Country/Region, Last Update, Confirmed, Suspected, Recovered, Deaths.

To show the trends related to the impact of COVID-19 on Gross Domestic Products, Travel and Tourism Industry and High Tech Products, the datasets are based on the surveys taken by Statista, over the time period of January 22 to March 12, 2020. Additional sources are the World Health Organization (WHO), Organisation for Economic Co-operation and Development (OECD), International Air Transport Association (IATA), etc.

\subsection{Trend Analysis}

In the proposed section, it was mentioned how the COVID-19 outbreak has affected the globe in the form of Gross Domestic Products, Travel and Tourism Industry and High Tech Products. While only three economic sectors were listed, there may be multiple analyses to a given sector. In order to analyze the effect of COVID-19, the research will be relying on several graphs. Based on the datasets, a plot may be generated to show the number of cumulative cases of COVID-19 worldwide along with a heat map to depict the locations that have been affected the most. To review the impact of COVID-19 on GDP, certain plot graphs depicting real GDP growth, monetary global GDP loss and percentage change in GDP due to the outbreak may be shown. To depict the impact of COVID-19 on the travel and tourism industry, graphs depicting global travel and tourism revenue in 2019 and the impact of the pandemic for 2020, revenue of the travel and tourism industry in 2019 and the projected impact of the pandemic in 2020, by world region and travel and tourism industry revenue in selected countries, may be shown. The impact of COVID-19 spread on the aviation industry has also been considered. Finally, plots have been generated to show how global high-tech product shipments are impacted by the outbreak.

\section{Results and Findings}

In this section, some graph plots based on data from the multiple datasets used, have been generated. Based on the graphs several observations can be made.

5.1 Number of cumulative cases of coronavirus (COVID-19) worldwide from January 22 to March 12, 2020, by day 


\section{Number of cumulative cases of coronavirus (COVID-19) worldwide}

January 22, 2020 to March 12, 2020

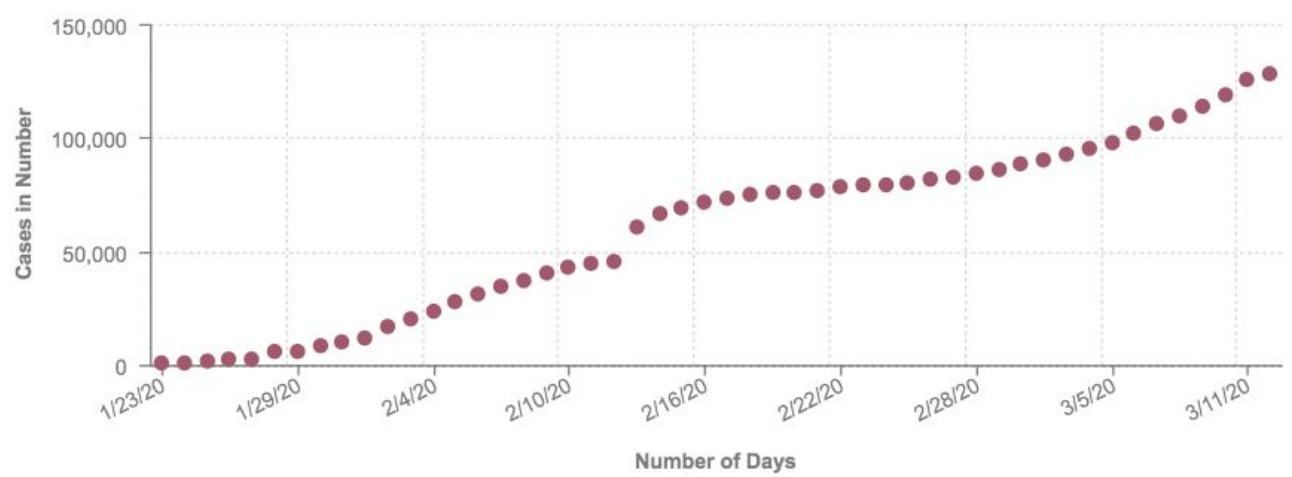

Fig 1. Plot showing the number of cumulative cases of COVID-19 worldwide

As is evident, the above graph (Fig.1) shows the number of COVID-19 cases over a time period of January 22, 2020, to March 12, 2020. Ever since its identification, the number of COVID-19 cases has increased significantly. Most than a million people have been affected.

5.2 Number of novel coronavirus (COVID-19) cases worldwide as of March 11, 2020, by country with a heat map

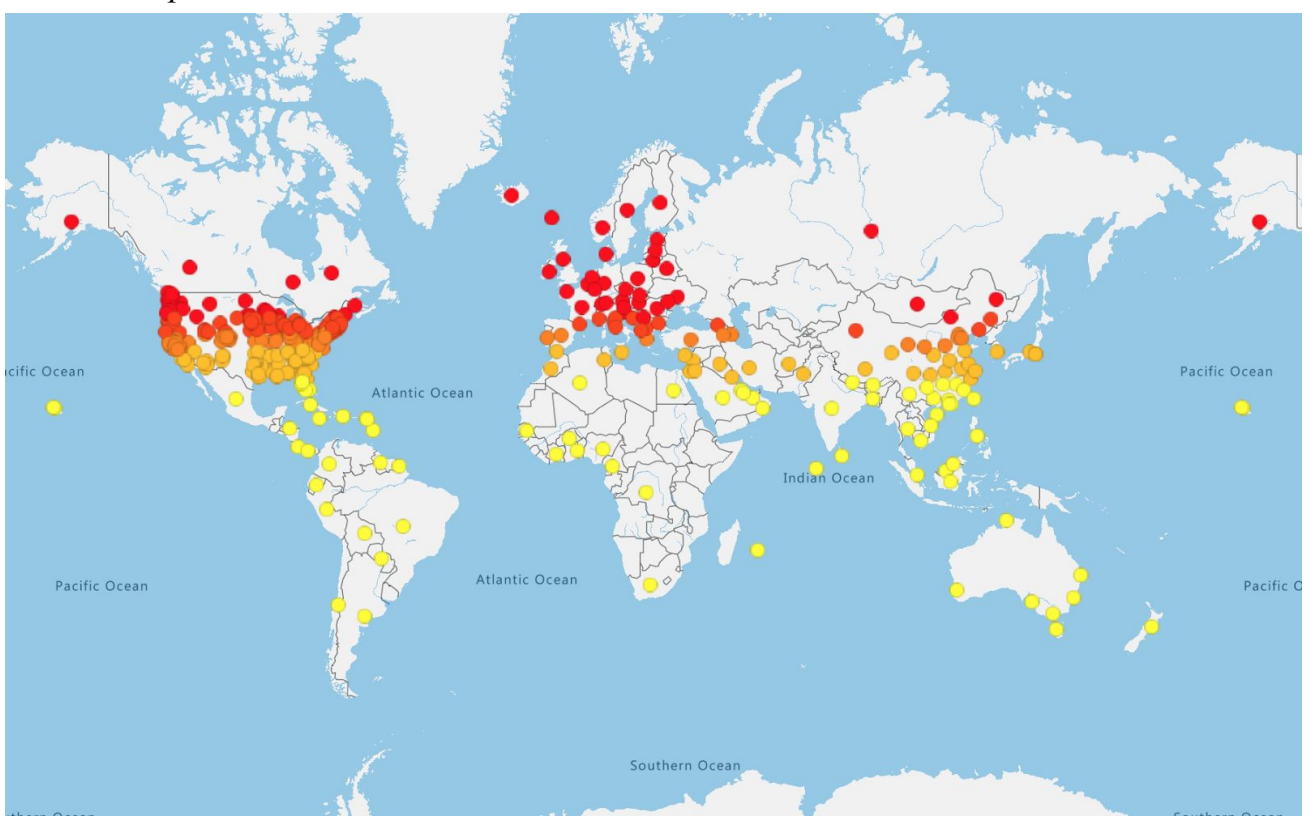

Fig 2. Heat map of the world depicting COVID-19 outbreak 
The above graph (Fig. 2) is a heat map showing the locations of the COVID-19 outage. The intensity is determined by the color of the points. While yellow depicts low intensity, red depicts high intensity, therefore a higher number of COVID-19 cases. It can be observed that the outbreak has spread across all the continents (except Antarctica). Regions of Asia, Europe, and North America have several red dots manifesting higher intensity of the outbreak.

\subsection{Forecasted global real Gross Domestic Product (GDP) growth due to coronavirus from 2019 to 2021 (in percentage)}

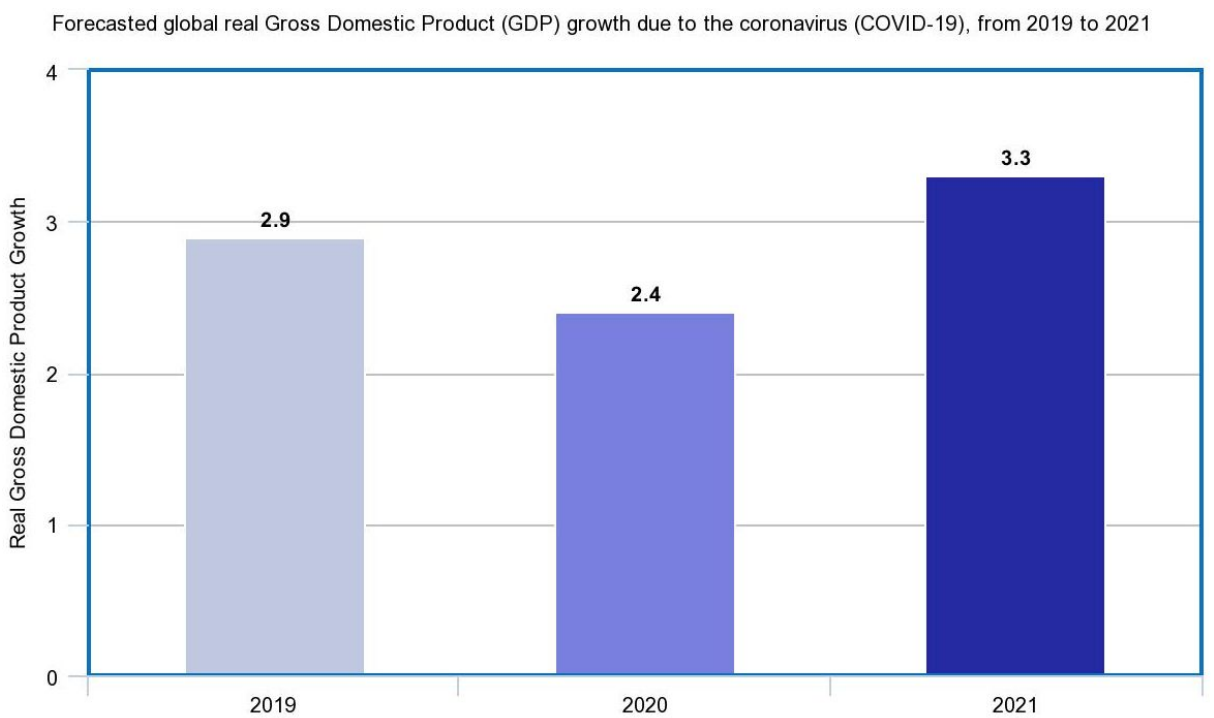

Fig 3. Graph depicting forecasted global real Gross Domestic Product (GDP) growth due to COVID-19 outbreak

The above graph (Fig.3) depicts the forecasted global real Gross Domestic Product (GDP) growth in percentage due to the COVID-19 outbreak. The global real Gross Domestic Product (GDP) grew by 2.9 percent in 2019. It is forecasted that COVID-19 will cause the global real GDP growth to decrease by 0.5 percent in 2020 compared to the previous year, to 2.4 percent growth. The global real GDP growth is expected to increase in 2021.

5.4 Forecasted monetary global real Gross Domestic Product (GDP) loss due to coronavirus from 2019 to 2021 


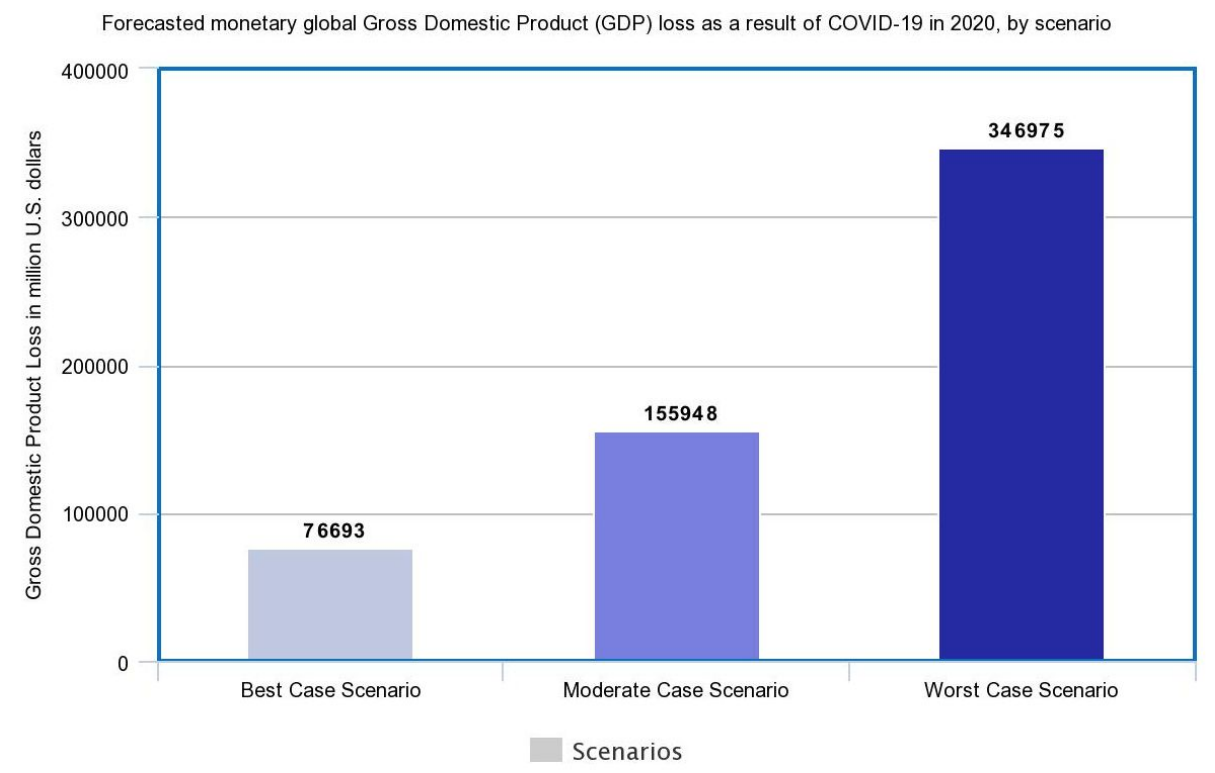

Fig 4. Graph depicting forecasted monetary global Gross Domestic Product (GDP) loss due to COVID-19 outbreak

The above graph (Fig. 4) depicts the forecasted monetary global Gross Domestic Product (GDP) loss due to the COVID-19 outbreak. Three different scenarios have been used to make the forecast. The Best case scenario refers to a two-month duration of travel bans and a sharp decline in domestic demand. The Moderate case scenario depicts a three-month duration of travel bans and a sharp decline in domestic demand. The Worst case scenario depicts a six-month duration of travel bans and a sharp decline in domestic demand. In the best-case scenario in 2020, which is defined as a two-month duration of travel bans and a sharp decline in domestic demand, the monetary loss of global Gross Domestic Product (GDP) is expected to be about 76.7 billion U.S. dollars due to the coronavirus (COVID-19) outbreak. In a worst-case scenario, defined as a six-month duration of travel bans, the global GDP is predicted to lose about 346.98 billion U.S. dollars.

5.5 Forecasted percentage change in global Gross Domestic Product (GDP) due to COVID-19 outbreak in 2020 
Forecasted percent change in global Gross Domestic Product (GDP) as a result of COVID-19 in 2020, by scenario

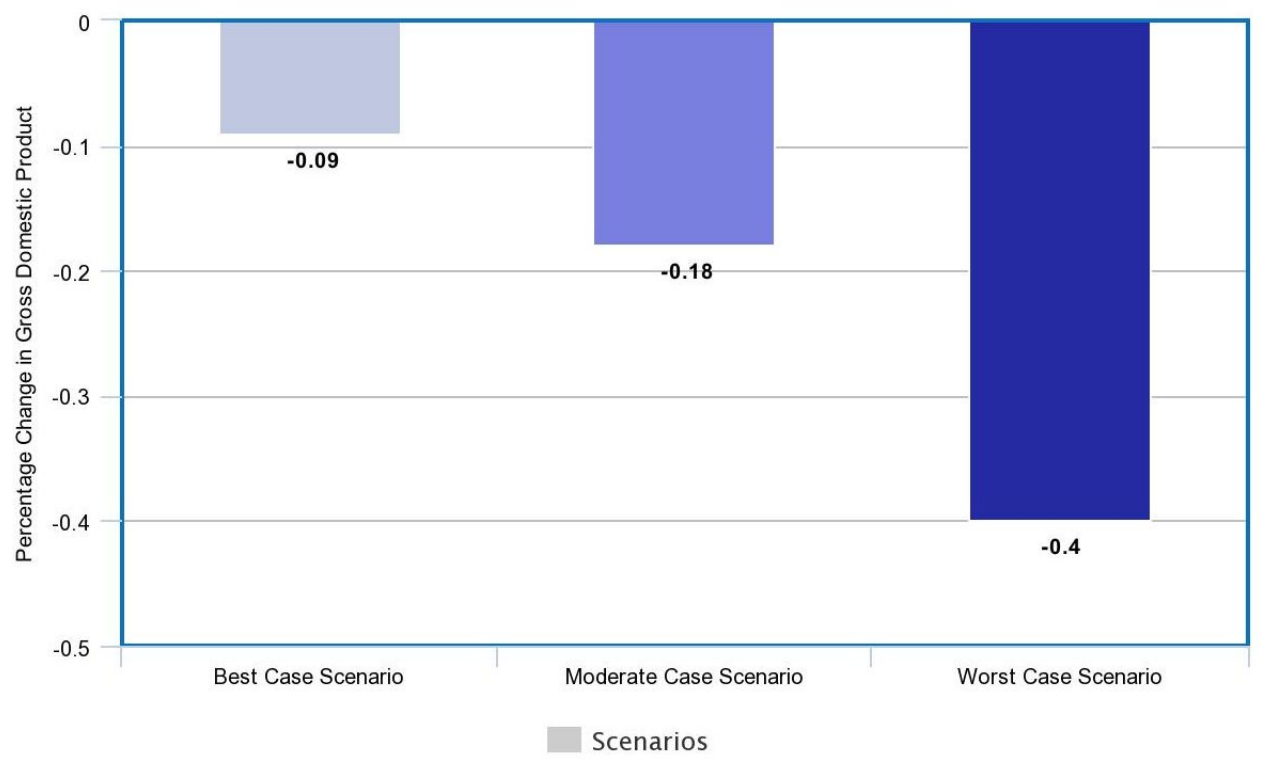

Fig 5. Graph depicting forecasted percentage global Gross Domestic Product (GDP) due to COVID-19 outbreak The above graph (Fig. 5) depicts the forecasted percent change in global Gross Domestic Product (GDP) due to the COVID-19 outbreak. Three different scenarios have been used to make the forecast. The Best case scenario refers to a two-month duration of travel bans and a sharp decline in domestic demand. The Moderate case scenario depicts a three-month duration of travel bans and a sharp decline in domestic demand. The Worst case scenario depicts a six-month duration of travel bans and a sharp decline in domestic demand. For the best-case scenario in 2020, the global Gross Domestic Product (GDP) is expected to decrease by 0.09 percent due to the outbreak, while in a worst-case scenario, the global GDP is predicted to decrease by 0.4 percent.

5.6 Global travel and tourism revenue in 2019 and impact of COVID-19 pandemic for 2020 forecast

Global travel and tourism revenue in 2019 and the impact of the coronavirus (COVID-19) pandemic for 2020 forecast

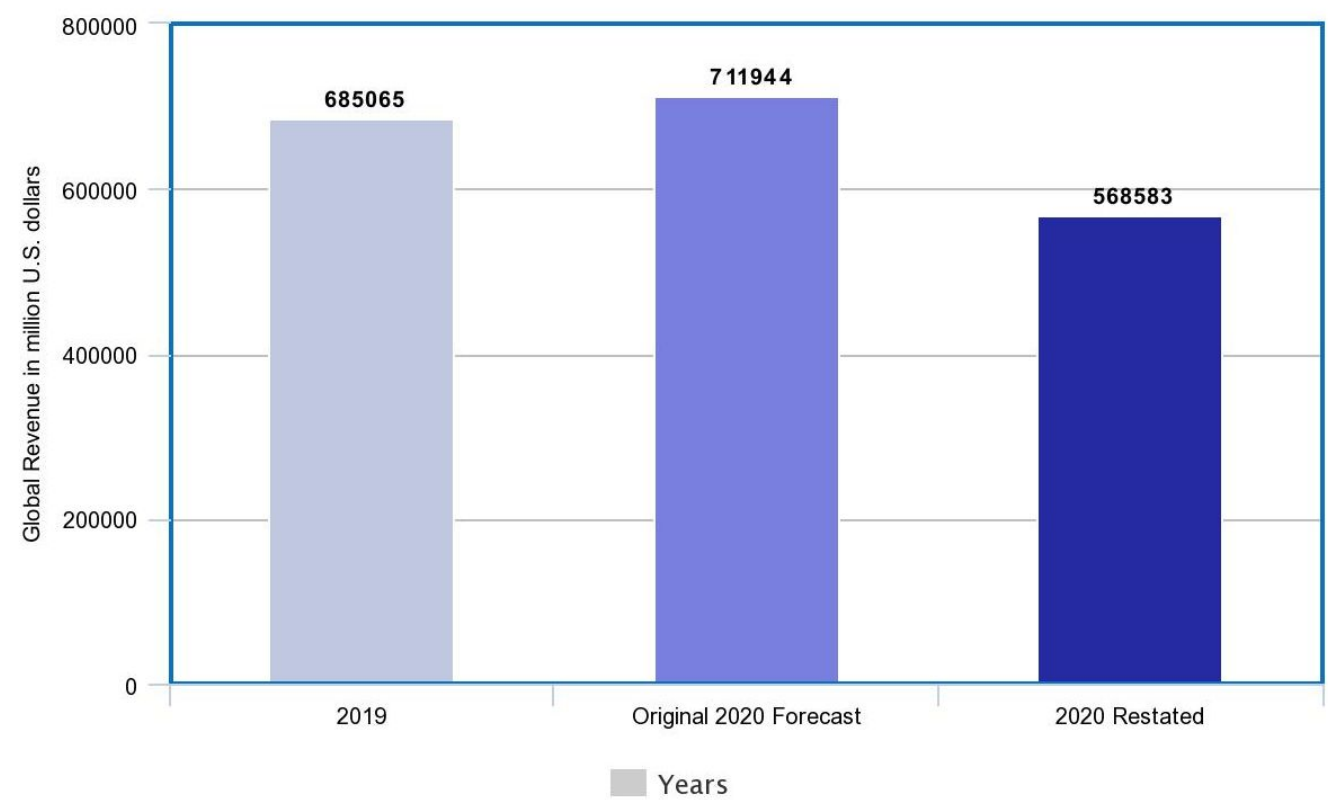


Fig.6 Graph depicting global travel and tourism revenue and the impact of COVID-19 outbreak

The above graph (Fig. 6) depicts the global travel and tourism revenue in 2019 and how the COVID-19 outbreak has an impact on the same for 2020. The epidemic is believed to have a major impact on travel and tourism for at least six months according to the International Air Transport Association (IATA). The decreased demand for flights is in par with the reduced demand for leisure trips. From the graph, it can be observed that the global revenue for the travel and tourism industry in 2020 is estimated to be around 568.6 billion U.S. dollars. It seems to have decreased by 17 percent with respect to 2019. This is remarkably lower than the original 2020 forecast of around 712 billion dollars.

5.7 Revenue of travel and tourism industry in 2019 and the projected impact of the COVID-19 pandemic in 2020, by world region

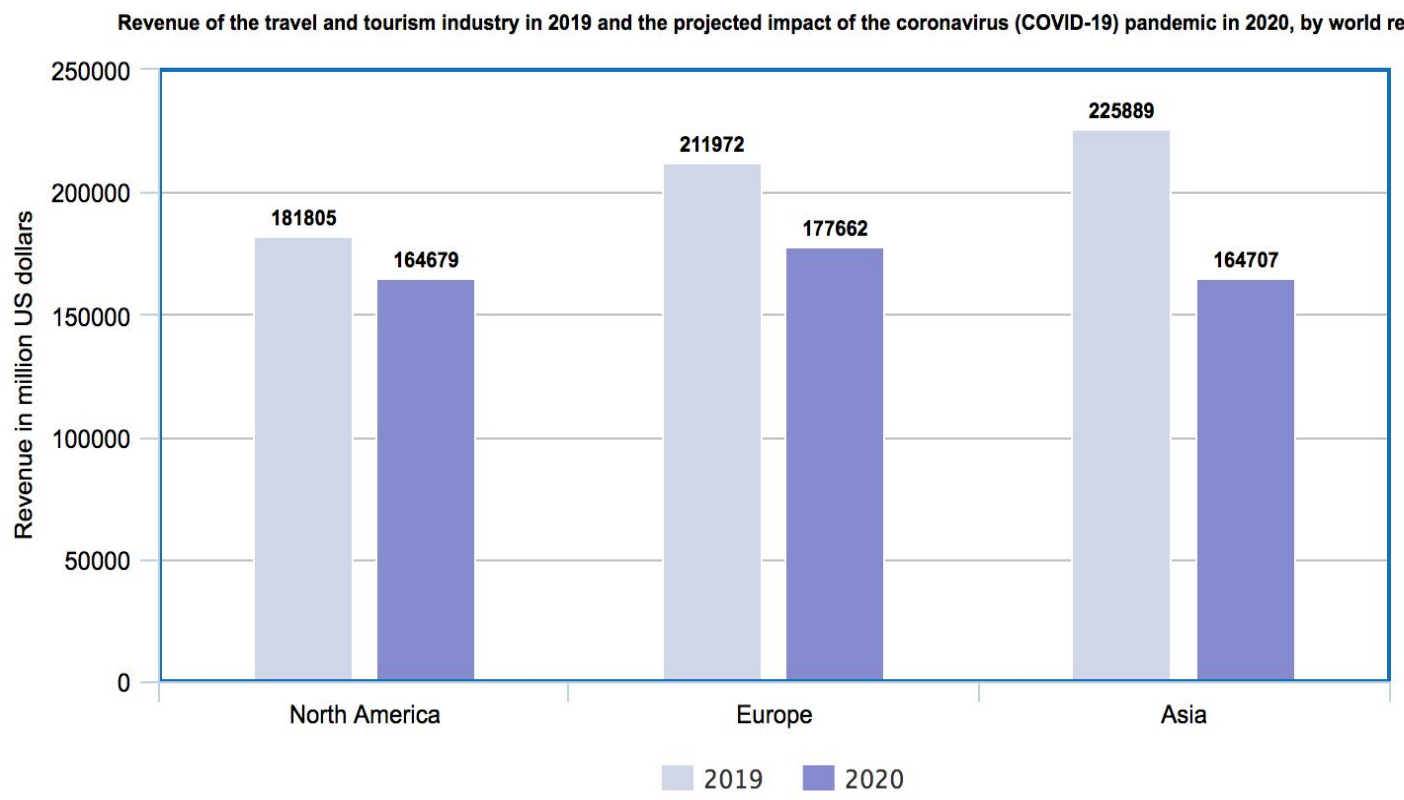

Fig.7 Graph depicting revenue of travel and tourism in 2019 and the projected impact of COVID-19 outbreak in 2020 by world region

The above graph (Fig. 7) depicts the revenue of travel and tourism in 2019 and the projected impact of the COVID-19 outbreak in 2020 by the world region. As is evident from the heat map (Fig. 2) three of the continents that have been most affected by the outbreak are North America, Europe, and Asia. There has been a decrease in the revenue for all three continents due to the COVID-19 outbreak. For North America, the revenue has decreased by $9.4 \%$, while it has decreased by $16.18 \%$ for Europe. It is interesting to know that the first case was identified in China (Asia) and the decrease in revenue for Asia is $27.08 \%$.

5.8 Travel and Tourism industry revenue in selected countries in 2019 and the projected impact of COVID-19 pandemic in 2020 
Travel and tourism industry revenue in selected countries in 2019 and projected impact of the coronavirus (COVID-19) pandemic in 2020

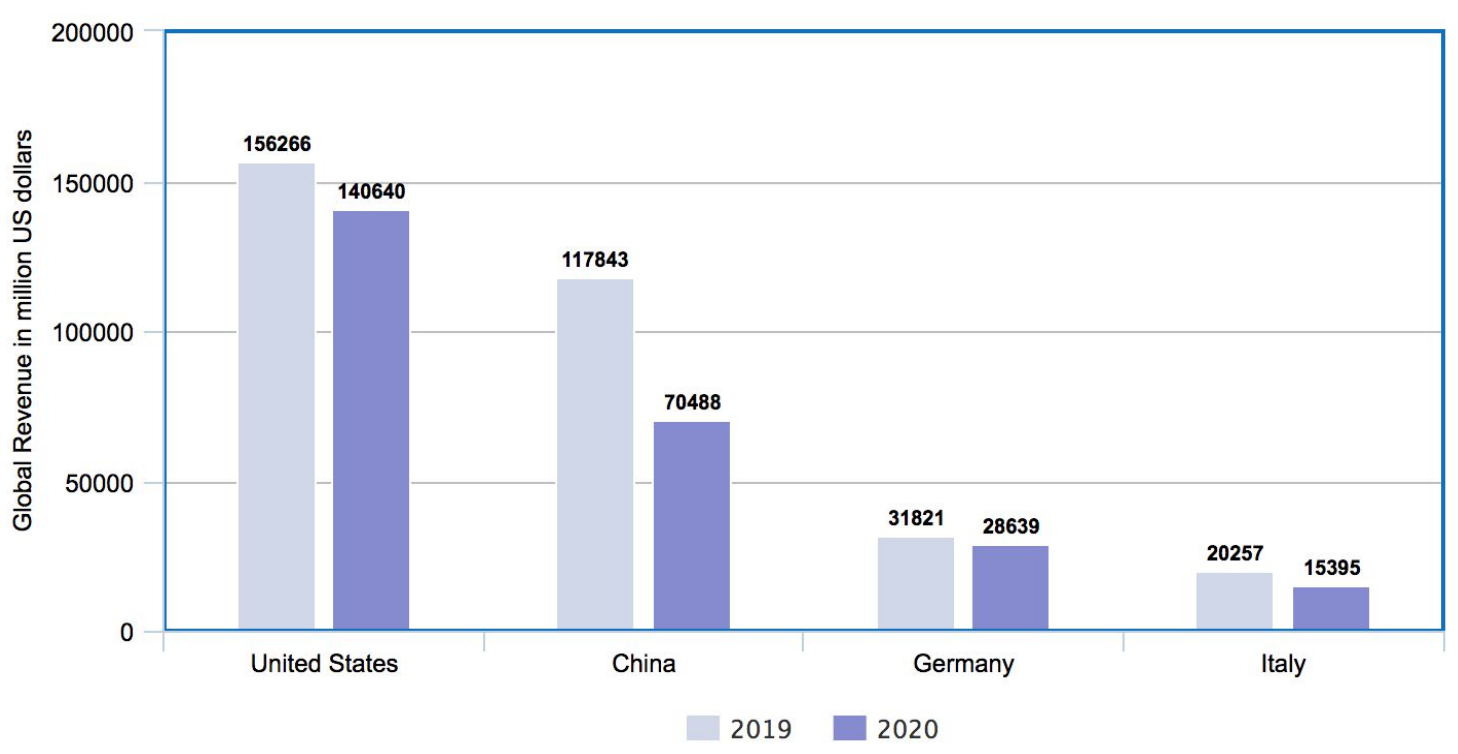

Fig.8 Graph depicting revenue of travel and tourism in 2019 and the projected impact of COVID-19 outbreak in 2020 for specific countries

The above graph (Fig. 8) depicts the revenue of travel and tourism in 2019 and the projected impact of COVID-19 for the same. In Section 3, it was discussed how the travel and tourism industry might be affected due to the COVID-19 outbreak. Some specific countries taken into account are the United States, China, Germany, and Italy. As is seen here, the decrease in revenue for the United States is almost 10\%, while for Germany and Italy the decrease is $10 \%$ and $24 \%$ respectively. China seems to be affected the most with an expected $40 \%$ decrease in the travel and tourism revenue.

5.9 Limited Spread impact scenario of COVID-19 outbreak on the aviation industry based on Passenger Numbers

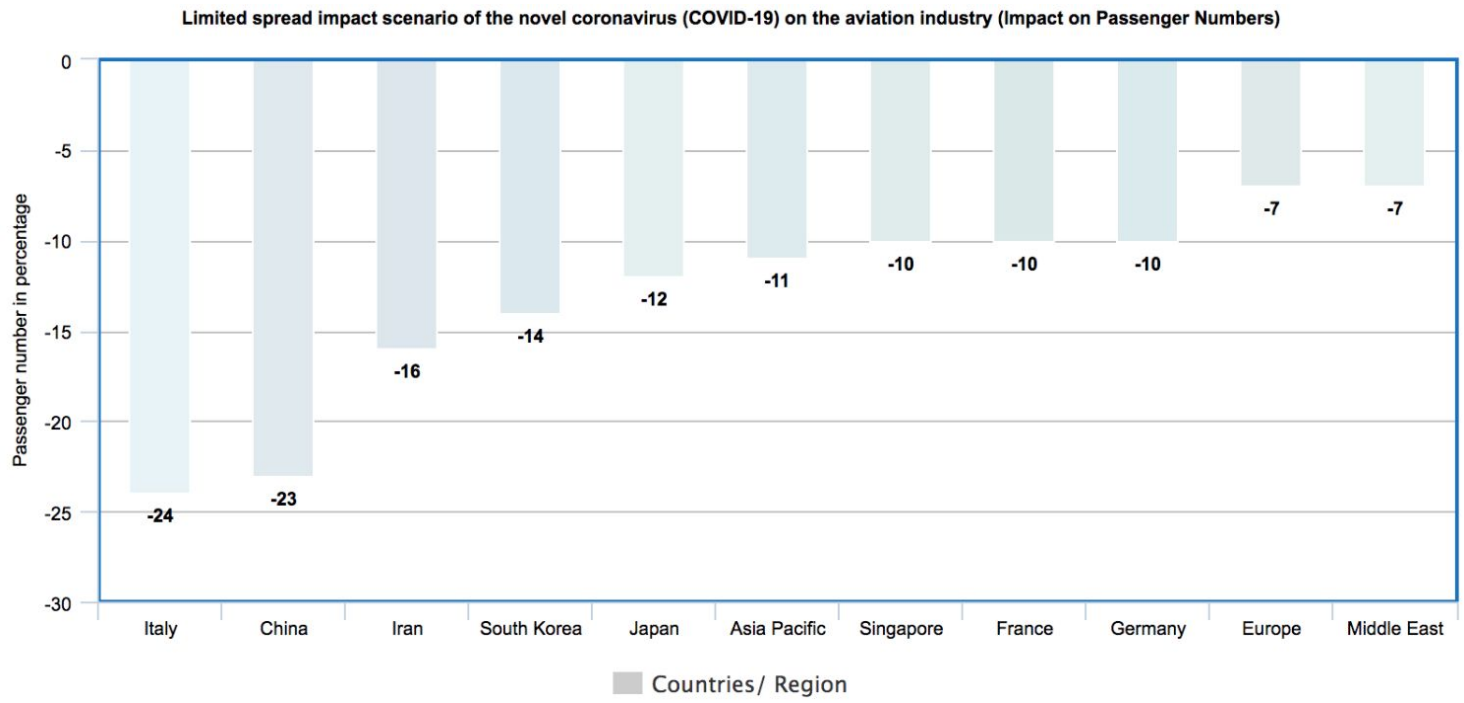


Fig. 9 Graph showing limited spread impact of COVID-19 on the aviation industry for the number of passengers

The above graph (Fig. 9) depicts the limited impact of the COVID-19 outbreak on the aviation industry based on the number of passengers. The countries taken into consideration are the ones that have 100 or more confirmed COVID-19 cases. Revenue figures do not add up to the global total because of route overlaps. An estimated 24 percent decline in the number of air passengers for Italy could be seen in this graph. As was mentioned in the proposed section, the COVID-19 outbreak has led to the lockdown of Italy. It is evident how the pandemic has affected the number of passengers flying across the globe. China, being the country with the most number of confirmed cases has suffered a $23 \%$ decline in the number of air passengers.

5.10 Limited Spread impact scenario of COVID-19 outbreak on the aviation industry based on Passenger Revenue

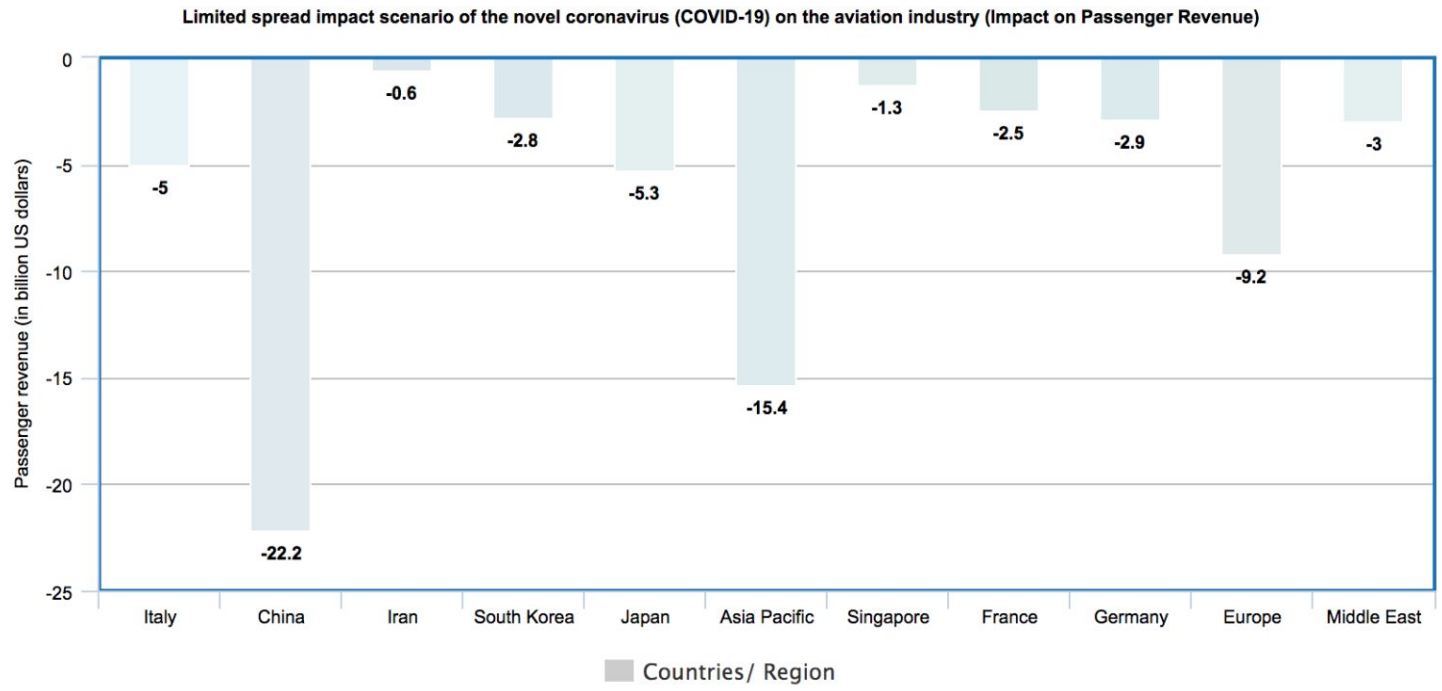

Fig. 10 Graph showing limited spread impact of COVID-19 on the aviation industry for the passenger revenue

The above graph (Fig. 10) depicts the limited impact of the COVID-19 outbreak on the aviation industry based on the number of passengers. The countries taken into consideration are the ones that have 100 or more confirmed COVID-19 cases. Revenue figures do not add up to the global total because of route overlaps. China seems to have suffered the most in terms of passenger revenues at 22.2 billion US dollars followed by the Asia Pacific (excluding China, Japan, Singapore, and South Korea) which seems to have suffered a passenger revenue loss of 15.4 billion US dollars.

5.11 Extensive Spread impact scenario of COVID-19 outbreak on the aviation industry based on Passenger Number 


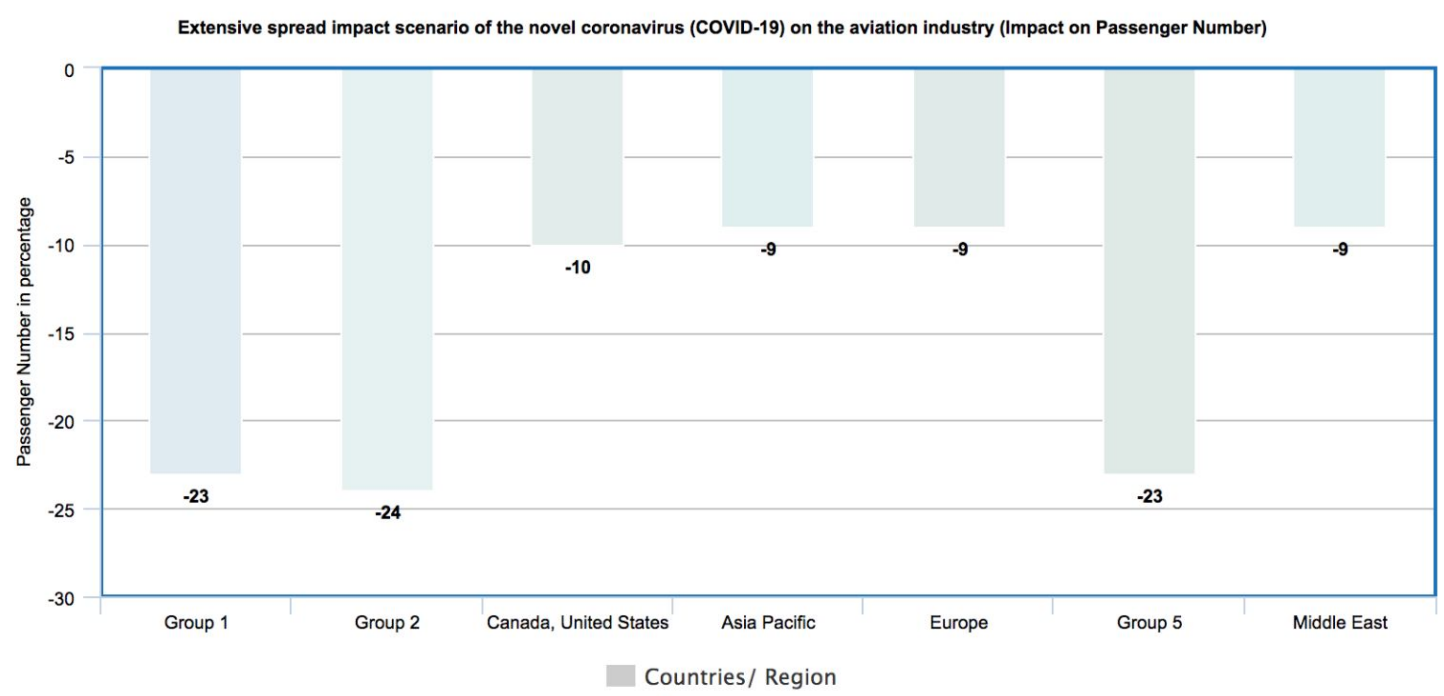

Fig. 11 Graph showing extensive spread impact of COVID-19 on the aviation industry for the number of passengers

The above graph (Fig. 11) depicts the limited impact of the COVID-19 outbreak on the aviation industry based on the number of passengers. The countries taken into consideration are the ones that have 100 or more confirmed COVID-19 cases. Revenue figures do not add up to the global total because of route overlaps. Group 2 (Austria, France, Italy, Germany, Netherlands, Norway, Spain, Switzerland, Sweden, the United Kingdom) witnesses the worst decrease in the number of passengers at $24 \%$ followed by Group 1 (Australia, China, Japan, Malaysia, Singapore, South Korea, Thailand, Vietnam) and Group 5 (Bahrain, Iraq, Iran, Kuwait, Lebanon, the United Arab Emirates) at $23 \%$ each. Canada and the United States witness a decline of $10 \%$ in the number of passengers while Asia Pacific (excluding other Asian countries mentioned here), and the middle east (excluding Group 5 countries) witness a decrease of $9 \%$ due to the COVID-19 outbreak.

5.12 Extensive Spread impact scenario of COVID-19 outbreak on the aviation industry based on Passenger Revenue

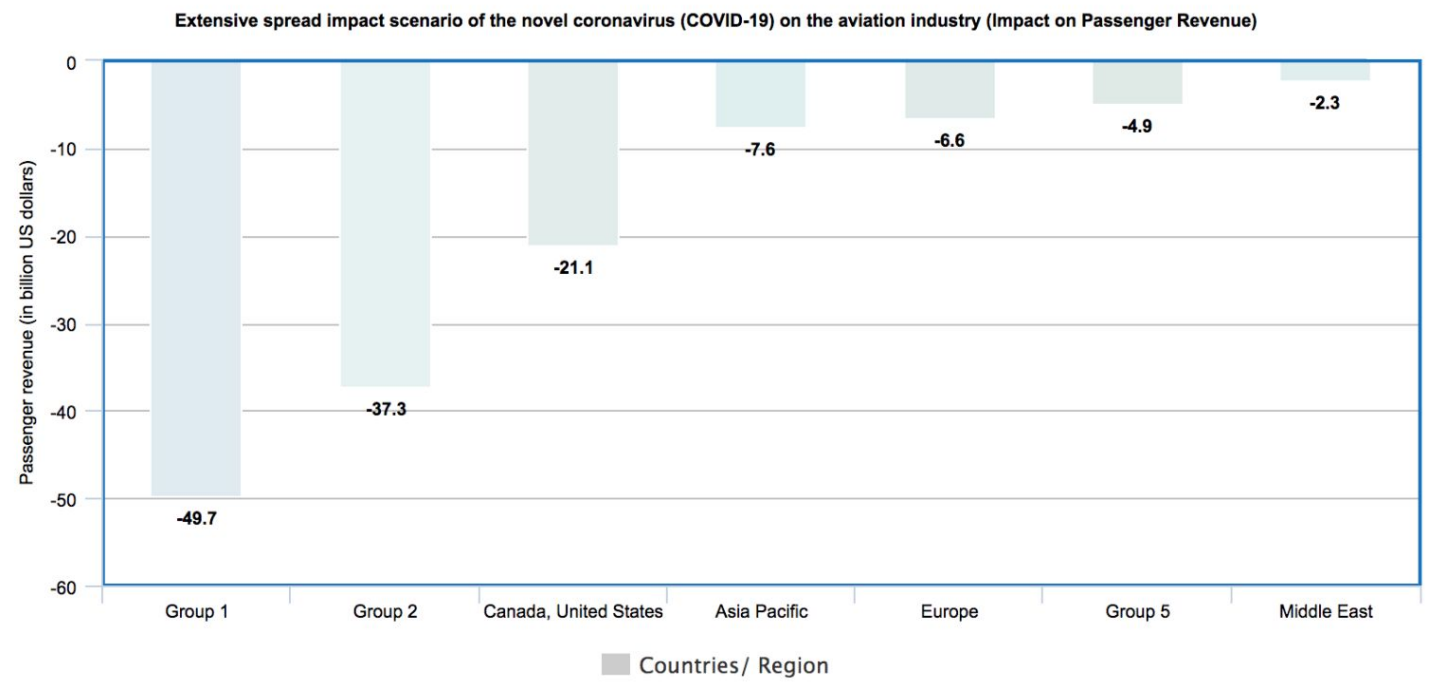

Fig. 12 Graph showing extensive spread impact of COVID-19 on the aviation industry for passenger revenue 
The above graph (Fig. 12) depicts the limited impact of the COVID-19 outbreak on the aviation industry based on the number of passengers. The countries taken into consideration are the ones that have 100 or more confirmed COVID-19 cases. Revenue figures do not add up to the global total because of route overlaps. Group 1 (Australia, China, Japan, Malaysia, Singapore, South Korea, Thailand, Vietnam) suffers the maximum decrease in passenger revenue at 49.7 billion US dollars followed by Group 2 (Austria, France, Italy, Germany, Netherlands, Norway, Spain, Switzerland, Sweden, the United Kingdom) which suffers a loss of 37.3 billion US dollars.

\subsection{Forecast of global high-tech product shipment impacted by COVID-19 outbreak for the first quarter of} 2020

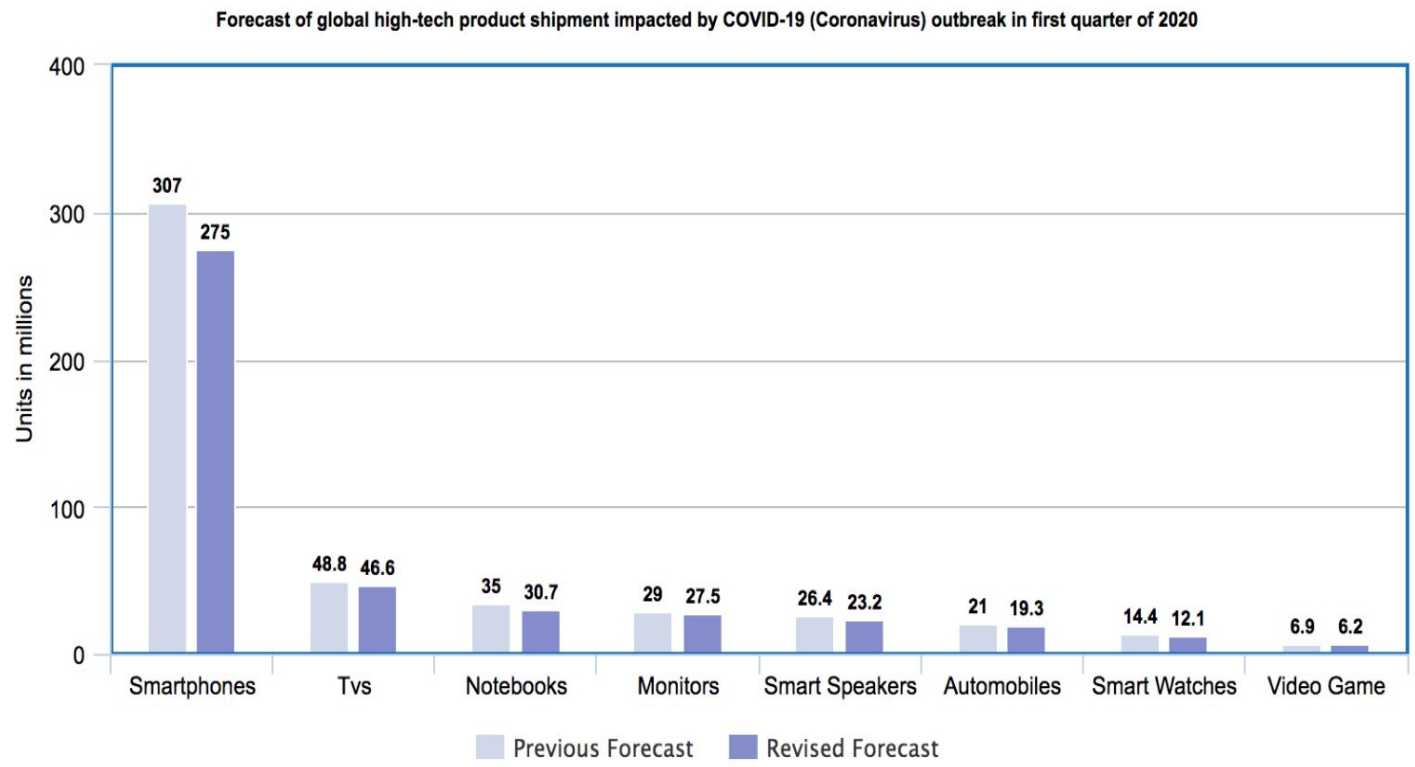

Fig. 13 Graph showing a comparison of forecasts for global high tech product shipment impacted by

\section{COVID-19 outbreak}

The above graph (Fig. 13) depicts a forecast of global high-tech product shipment impacted by the COVID-19 outbreak for the first quarter of 2020. The outbreak of COVID-19 is expected to influence the production and shipment of key technology products in the first quarter of 2020. As is evident there is a decrease in the shipment of all the global high tech products considered. The shipment of smartphones and video game consoles is expected to decline significantly by $10 \%$. Televisions and Notebooks may witness a decline, at $4.5 \%$ and $12 \%$ respectively. Almost a $16 \%$ decline is seen for smartwatches due to the COVID-19 outbreak.

As suggested in the proposed work section, three economic sectors that may be impacted by the COVID-19 outbreak have been highlighted, i.e. Gross Domestic Product, Travel and Tourism Industry and High Tech Products shipment. Several graphs were presented to highlight how the COVID-19 outbreak has managed to travel across the globe and do more than just infect people. As is evident all the economic sectors taken into consideration have suffered due to the COVID-19 outbreak.

A comparative analysis of some existing works on COVID-19 has been presented to justify the proposed work. The comparative analysis is as follows (Table 2) 
Table 2: Comparative analysis of our proposed work with existing works

\begin{tabular}{|c|c|c|c|}
\hline Year and Author & Research & $\begin{array}{l}\text { Parameter/ } \\
\text { Methodology }\end{array}$ & Results \\
\hline (Stoecklin et al, 2020) & $\begin{array}{l}\text { Study on the first cases } \\
\text { of coronavirus } \\
\text { (COVID-19 in France }\end{array}$ & $\begin{array}{l}\text { A French Surveillance } \\
\text { system was considered } \\
\text { to analyze the cases. A } \\
\text { standardized } \\
\text { investigation form } \\
\text { collecting } \\
\text { socio-demographic } \\
\text { information, clinical } \\
\text { details and history of } \\
\text { exposure was taken into } \\
\text { account. }\end{array}$ & $\begin{array}{l}\text { A very limited number } \\
\text { of patients considered } \\
\text { for analysis (three). The } \\
\text { time frame is too } \\
\text { limited (January } 10 \text {, } \\
2020 \text {, to January } 14 \text {, } \\
2020 \text { ). }\end{array}$ \\
\hline (Li et al, 2020) & $\begin{array}{l}\text { Study on the Early } \\
\text { Transmission Dynamics } \\
\text { of COVID- } 2019\end{array}$ & $\begin{array}{l}\text { Analyzed detailed } \\
\text { epidemiologic } \\
\text { information collected } \\
\text { during field } \\
\text { investigations, } \\
\text { including exposure } \\
\text { history, timelines of } \\
\text { events, and close } \\
\text { contact identification. } \\
\text { Places that were visited } \\
\text { by the patients recently } \\
\text { were also investigated. }\end{array}$ & $\begin{array}{l}\text { Limited dataset }(425 \\
\text { confirmed cases) } \\
\text { Limited time period } \\
\text { (December } 10,2020 \text {, to } \\
\text { January } 04,2020) \\
\text { Several false alarms } \\
\text { regarding symptoms of } \\
\text { pneumonia. }\end{array}$ \\
\hline Chinnazi et al, 2020 & $\begin{array}{l}\text { Research on the effect } \\
\text { of travel restrictions on } \\
\text { the spread of the } \\
\text { COVID-19 outbreak. }\end{array}$ & $\begin{array}{l}\text { Global metapopulation } \\
\text { disease transmission } \\
\text { mode }\end{array}$ & $\begin{array}{l}\text { Cases have been listed } \\
\text { from } 23 \text { January } 2020 \text {, } \\
\text { so it is possible that a } \\
\text { lot of Chinese cities } \\
\text { might have already } \\
\text { been infected by then. } \\
\text { The research takes into } \\
\text { account travel } \\
\text { restrictions to and fro } \\
\text { Mainland China, while } \\
\text { COVID-19 is a global } \\
\text { pandemic }\end{array}$ \\
\hline Qi et. al, 2020 & $\begin{array}{l}\text { Large scale survey of } \\
\text { the psychological } \\
\text { distress among Chinese } \\
\text { people due to the } \\
\text { COVID-19 epidemic }\end{array}$ & $\begin{array}{l}\text { Self-reporting } \\
\text { questionnaire and } \\
\text { several questions } \\
\text { related to demographic } \\
\text { data (ie, province, } \\
\text { gender, age, education, } \\
\text { and occupation), } \\
\text { frequency of anxiety, }\end{array}$ & $\begin{array}{l}\text { While the research is a } \\
\text { large scale survey, due } \\
\text { to the lack of empirical } \\
\text { data (trends and } \\
\text { graphs), it is difficult to } \\
\text { anticipate the overall } \\
\text { results. Further, the } \\
\text { study was restricted to }\end{array}$ \\
\hline
\end{tabular}




\begin{tabular}{|c|c|c|c|}
\hline & & $\begin{array}{l}\text { depression, specific } \\
\text { phobias, cognitive } \\
\text { change, avoidance and } \\
\text { compulsive behavior, } \\
\text { physical symptoms, and } \\
\text { loss of social } \\
\text { functioning in the past } \\
\text { week. }\end{array}$ & $\begin{array}{l}\text { only China and has data } \\
\text { up to } 10 \text { February } 2020 .\end{array}$ \\
\hline Gallego et. al, 2020 & $\begin{array}{l}\text { Implications of } \\
\text { COVID-19 on Tokyo } \\
2020 \text { Summer Olympic } \\
\text { Games }\end{array}$ & $\begin{array}{l}\text { Anticipating the } \\
\text { number of people who } \\
\text { will be attending the } \\
\text { event, } \\
\text { The location from } \\
\text { Yokohama port to the } \\
\text { venues of the game }\end{array}$ & $\begin{array}{l}\text { The study does not } \\
\text { feature any graph plots } \\
\text { or trends (empirical } \\
\text { study or experimental } \\
\text { analysis) }\end{array}$ \\
\hline Sun et. al, 2020 & $\begin{array}{l}\text { Study on COVID-19 } \\
\text { based on current } \\
\text { evidence }\end{array}$ & $\begin{array}{l}\text { Epidemiological } \\
\text { characteristics, } \\
\text { mechanism, symptoms, } \\
\text { diagnosis prevention, } \\
\text { treatment }\end{array}$ & $\begin{array}{l}\text { The study does not take } \\
\text { into account any } \\
\text { empirical study or } \\
\text { experimental analysis. }\end{array}$ \\
\hline Proposed Work, 2020 & $\begin{array}{l}\text { Survey on some Global } \\
\text { effects of COVID-19 } \\
\text { outbreak }\end{array}$ & $\begin{array}{l}\text { Gross Domestic } \\
\text { Product, Travel and } \\
\text { Tourism Industry, High } \\
\text { Tech Products shipment }\end{array}$ & $\begin{array}{l}\text { Presented the outbreak } \\
\text { of COVID-19 across } \\
\text { the globe using graph } \\
\text { plots and heat maps. } \\
\text { Justified the effect of } \\
\text { COVID-19 on Gross } \\
\text { Domestic Product, } \\
\text { Travel and Tourism } \\
\text { Industry, High Tech } \\
\text { Products shipment } \\
\text { empirically, through } \\
\text { graphs. }\end{array}$ \\
\hline
\end{tabular}

\section{Conclusion and Future Work}

The novel coronavirus or the COVID-19, which was first identified in Wuhan, China took only a couple of months to be declared an epidemic and was soon labeled as a pandemic after that. It has affected more than a million people over the world and the number of cases keeps on rising. The effects of the outbreak are not limited to this but are all seen in other spheres of life. Thus it has the potential to cause global effects. In this paper, three economic spheres have been identified i.e. Gross Domestic Product (GDP), Travel and Tourism Industry, High Tech Products shipment and COVID-19 outbreak is believed to have an impact on all three spheres. Using sufficient survey data, it has been justified how the COVID-19 outbreak has affected all these spheres, by plotting multiple graphs. Such outbreaks are sudden and may affect the globe sooner than anticipated. This study would be beneficial to industries and researchers to prepare better for such a global crisis and would assist them in contemplating specific scenarios in case of an epidemic or pandemic in the future. 
The global effects do not end here. Due to globalization several industries are interconnected and interdependent. In the future, it would be interesting to observe the effect of COVID-19 on more such industries with an updated dataset.

\section{Compliance with Ethical Standards}

Funding: This research received no external funding.

Acknowledgments: The authors would like to thank the Editor-in-Chief and the anonymous reviewers for their valuable comments and suggestions.

Conflicts of Interest: There are no conflicts of interest. This research does not involve any human or animal participation.

\section{References}

Allam, Z., \& Jones, D. S. (2020, March). On the Coronavirus (COVID-19) Outbreak and the Smart City Network: Universal Data Sharing Standards Coupled with Artificial Intelligence (AI) to Benefit Urban Health Monitoring and Management. In Healthcare (Vol. 8, No. 1, p. 46). Multidisciplinary Digital Publishing Institute.

Chinazzi, M., Davis, J. T., Ajelli, M., Gioannini, C., Litvinova, M., Merler, S., ... \& Viboud, C. (2020). The effect of travel restrictions on the spread of the 2019 novel coronavirus (COVID-19) outbreak. Science.

Columbus, C., Brust, K. B., \& Arroliga, A. C. (2020, February). 2019 novel coronavirus: an emerging global threat. In Baylor University Medical Center Proceedings (pp. 1-4). Taylor \& Francis.

Gallego, V., Nishiura, H., Sah, R., \& Rodriguez-Morales, A. J. (2020). The COVID-19 outbreak and implications for the Tokyo 2020 Summer Olympic Games. Travel medicine and infectious disease, 101604.

Gates, B. (2020). Responding to Covid-19—A Once-in-a-Century Pandemic?. New England Journal of Medicine.

Gilbert, M., Pullano, G., Pinotti, F., Valdano, E., Poletto, C., Boëlle, P. Y., ... \& Gutierrez, B. (2020). Preparedness and vulnerability of African countries against importations of COVID-19: a modelling study. The Lancet.

Guarner, J. (2020). Three Emerging Coronaviruses in Two Decades: The Story of SARS, MERS, and Now COVID-19.

Habibi, R., Burci, G. L., de Campos, T. C., Chirwa, D., Cinà, M., Dagron, S., ... \& Negri, S. (2020). Do not violate the International Health Regulations during the COVID-19 outbreak. The Lancet.

Heymann, D. L., \& Shindo, N. (2020). COVID-19: what is next for public health?. The Lancet. 
Jiang, S., Du, L., \& Shi, Z. (2020). An emerging coronavirus causing pneumonia outbreak in Wuhan, China: calling for developing therapeutic and prophylactic strategies. Emerging Microbes \& Infections, 9(1), 275-277.

Koh, D. (2020). Occupational risks for COVID-19. Occupational Medicine.

Li, Q., Guan, X., Wu, P., Wang, X., Zhou, L., Tong, Y., .. \& Xing, X. (2020). Early transmission dynamics in Wuhan, China, of novel coronavirus-infected pneumonia. New England Journal of Medicine.

Maclntyre, C. R. (2020). Global spread of COVID-19 and pandemic potential. Global Biosecurity, 1(3).

Mustapha, J. O., Adedokun, K. A., \& Abdullahi, I. N. (2020). Public health preparedness towards COVID-19 outbreak in Nigeria. Asian Pacific Journal of Tropical Medicine, 13.

Novel, C. P. E. R. E. (2020). The epidemiological characteristics of an outbreak of 2019 novel coronavirus diseases (COVID-19) in China. Zhonghua liu xing bing xue za zhi= Zhonghua liuxingbingxue zazhi, 41(2), 145.

Porcheddu, R., Serra, C., Kelvin, D., Kelvin, N., \& Rubino, S. (2020). Similarity in Case Fatality Rates (CFR) of COVID-19/SARS-COV-2 in Italy and China. The Journal of Infection in Developing Countries, 14(02), 125-128.

Qiu, J., Shen, B., Zhao, M., Wang, Z., Xie, B., \& Xu, Y. (2020). A nationwide survey of psychological distress among Chinese people in the COVID-19 epidemic: implications and policy recommendations.

Stoecklin, S. B., Rolland, P., Silue, Y., Mailles, A., Campese, C., Simondon, A., ... \& Yamani, E. (2020). First cases of coronavirus disease 2019 (COVID-19) in France: surveillance, investigations and control measures, January 2020. Eurosurveillance, 25(6), 2000094.

Sun, P., Lu, X., Xu, C., Sun, W., \& Pan, B. (2020). Understanding of COVID-19 based on current evidence. Journal of Medical Virology.

Wong, J. E., Leo, Y. S., \& Tan, C. C. (2020). COVID-19 in Singapore-Current Experience: Critical Global Issues That Require Attention and Action. JAMA.

Zhou, P., Yang, X. L., Wang, X. G., Hu, B., Zhang, L., Zhang, W., ... \& Chen, H. D. (2020). A pneumonia outbreak associated with a new coronavirus of probable bat origin. Nature, 1-4. 


\section{Figures}

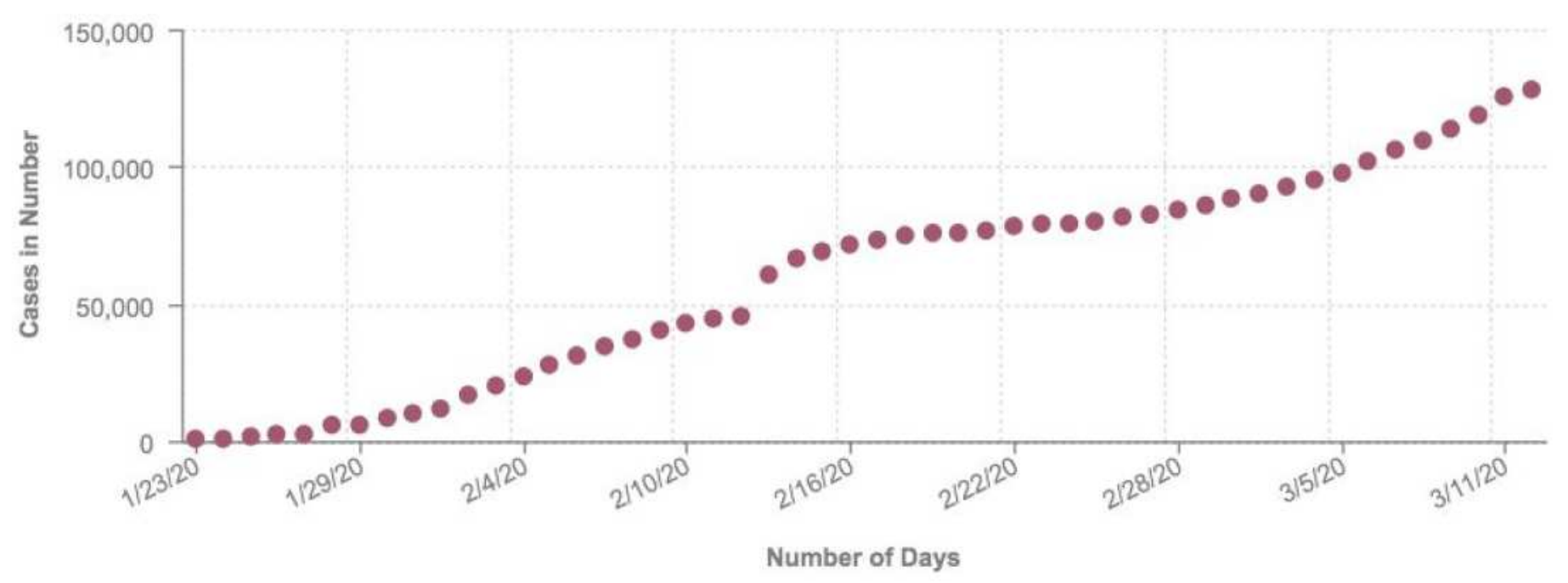

\section{Figure 1}

Plot showing the number of cumulative cases of COVID-19 worldwide

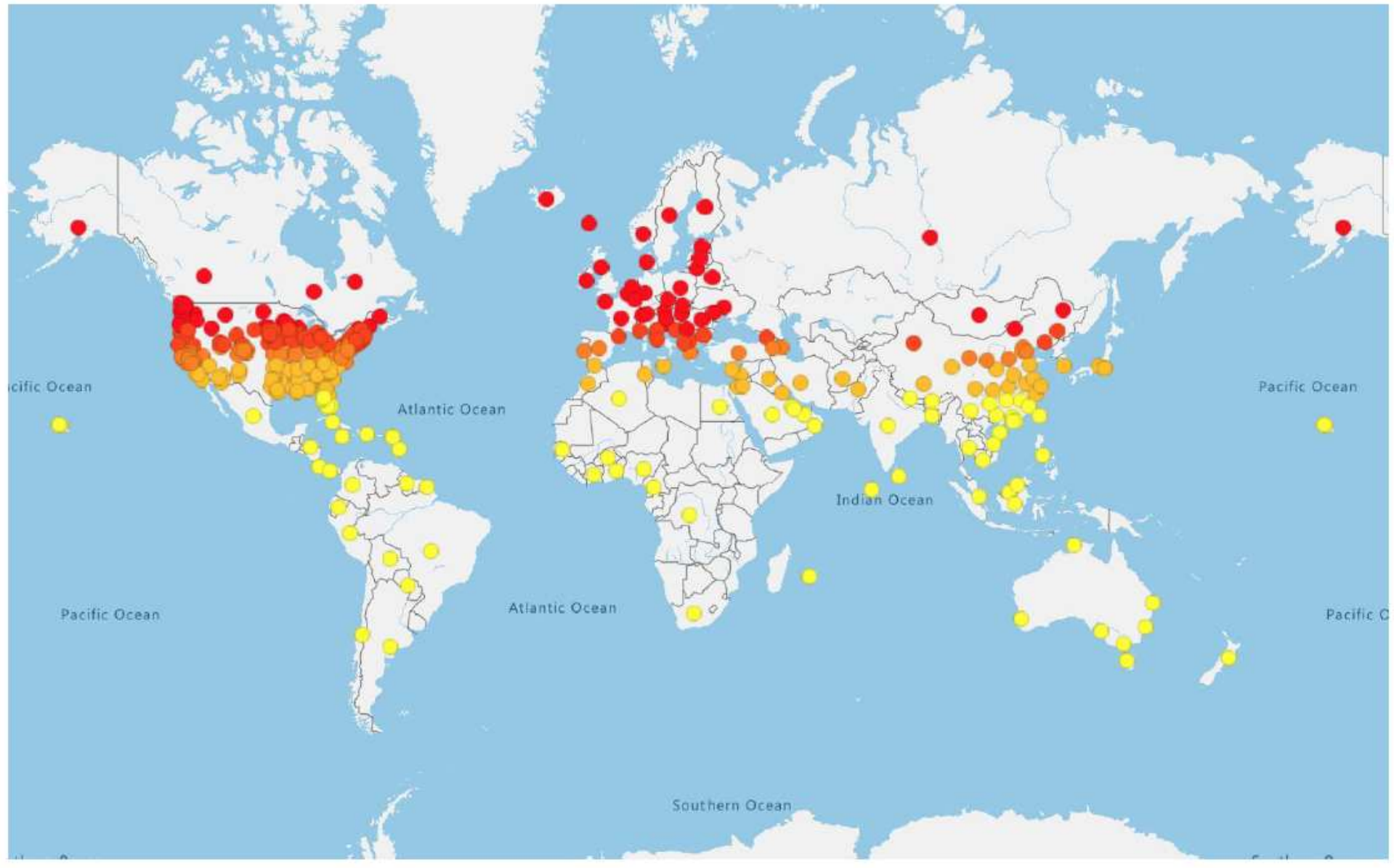

Figure 2 
Heat map of the world depicting COVID-19 outbreak. Note: The designations employed and the presentation of the material on this map do not imply the expression of any opinion whatsoever on the part of Research Square concerning the legal status of any country, territory, city or area or of its authorities, or concerning the delimitation of its frontiers or boundaries. This map has been provided by the authors.

Forecasted global real Gross Domestic Product (GDP) growth due to the coronavirus (COVID-19), from 2019 to 2021

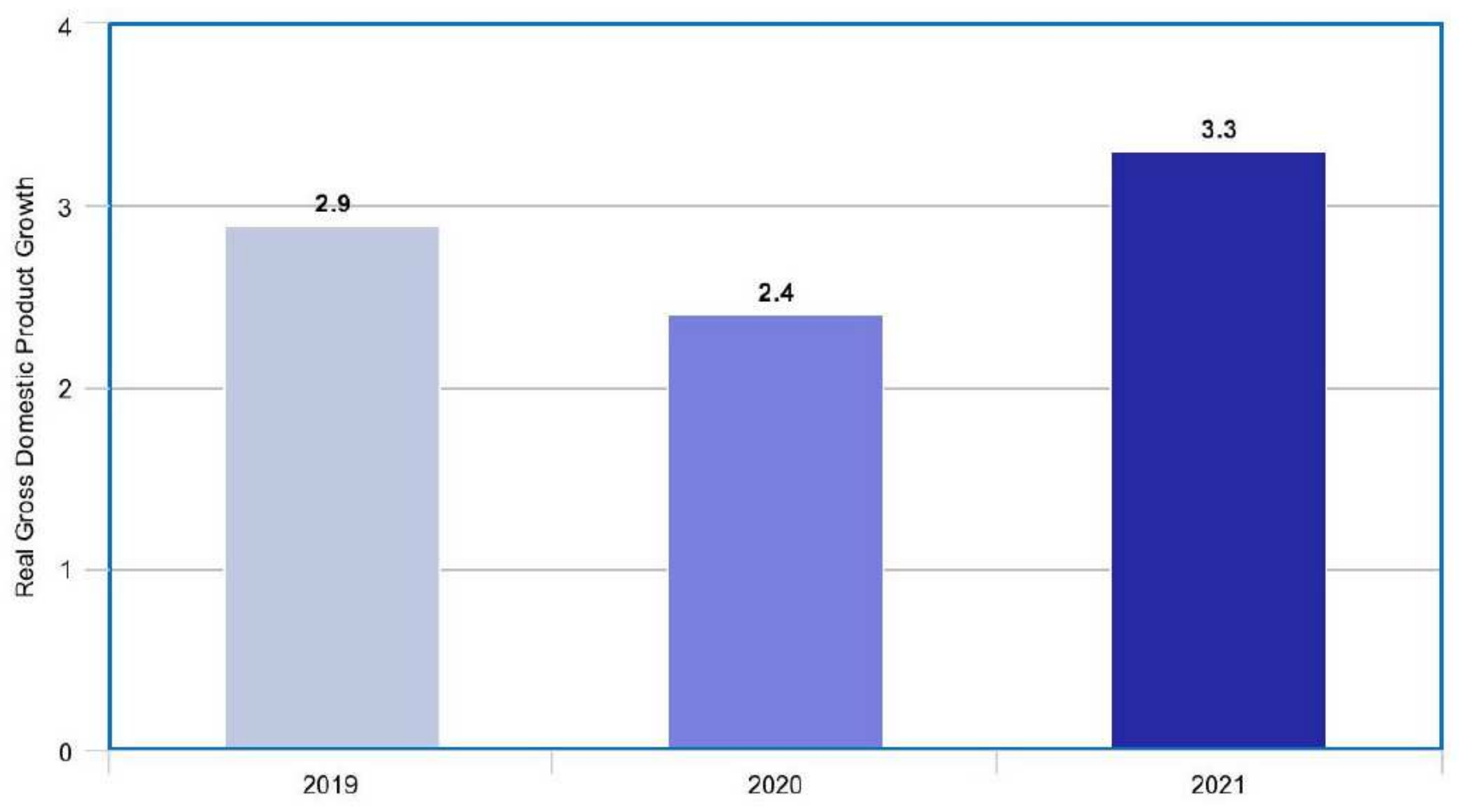

Figure 3

Graph depicting forecasted global real Gross Domestic Product (GDP) growth due to COVID-19 outbreak 
Forecasted monetary global Gross Domestic Product (GDP) loss as a result of COVID-19 in 2020, by scenario

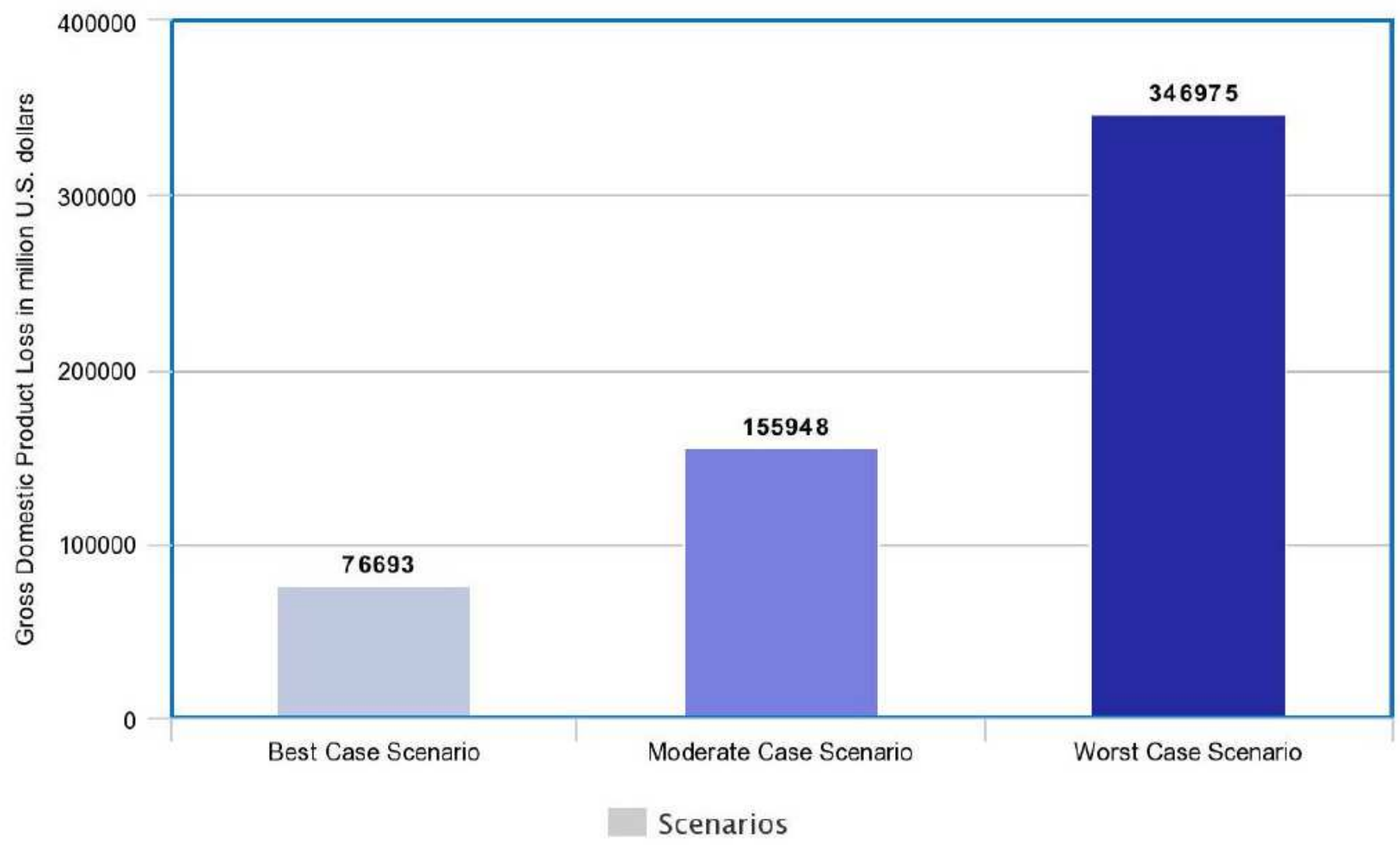

\section{Figure 4}

Graph depicting forecasted monetary global Gross Domestic Product (GDP) loss due to COVID-19 outbreak 
Forecasted percent change in global Gross Domestic Product (GDP) as a result of COVID-19 in 2020, by scenario

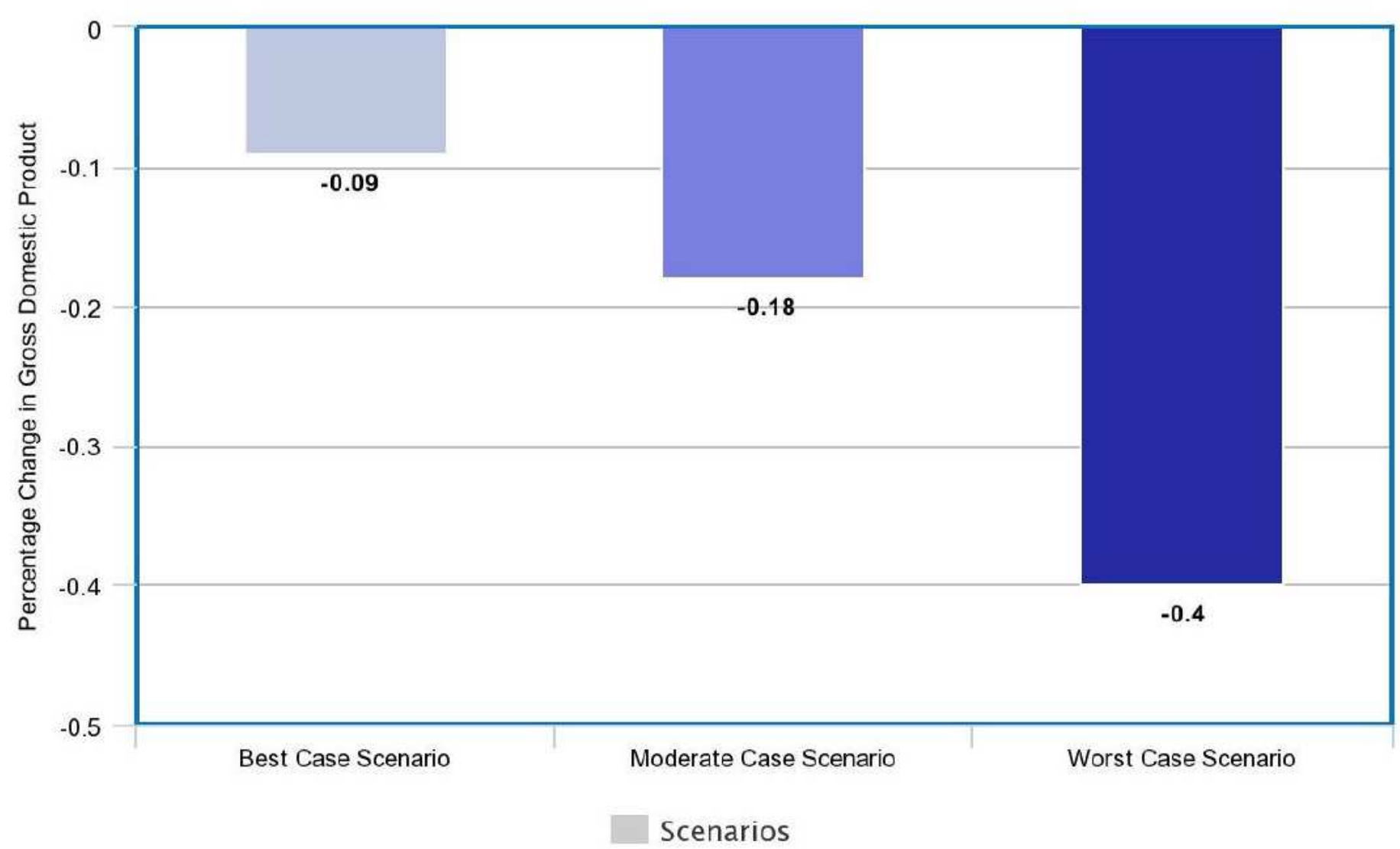

\section{Figure 5}

Graph depicting forecasted percentage global Gross Domestic Product (GDP) due to COVID-19 outbreak The above graph ( Fig. 5 ) depicts the forecasted percent change in global Gross Domestic Product (GDP) due to the COVID-19 outbreak. Three different scenarios have been used to make the forecast. The Best case scenario refers to a two-month duration of travel bans and a sharp decline in domestic demand. The Moderate case scenario depicts a three-month duration of travel bans and a sharp decline in domestic demand. The Worst case scenario depicts a six-month duration of travel bans and a sharp decline in domestic demand. For the best-case scenario in 2020, the global Gross Domestic Product (GDP) is expected to decrease by 0.09 percent due to the outbreak, while in a worst-case scenario, the global GDP is predicted to decrease by 0.4 percent. 
Global travel and tourism revenue in 2019 and the impact of the coronavirus (COVID-19) pandemic for 2020 forecast

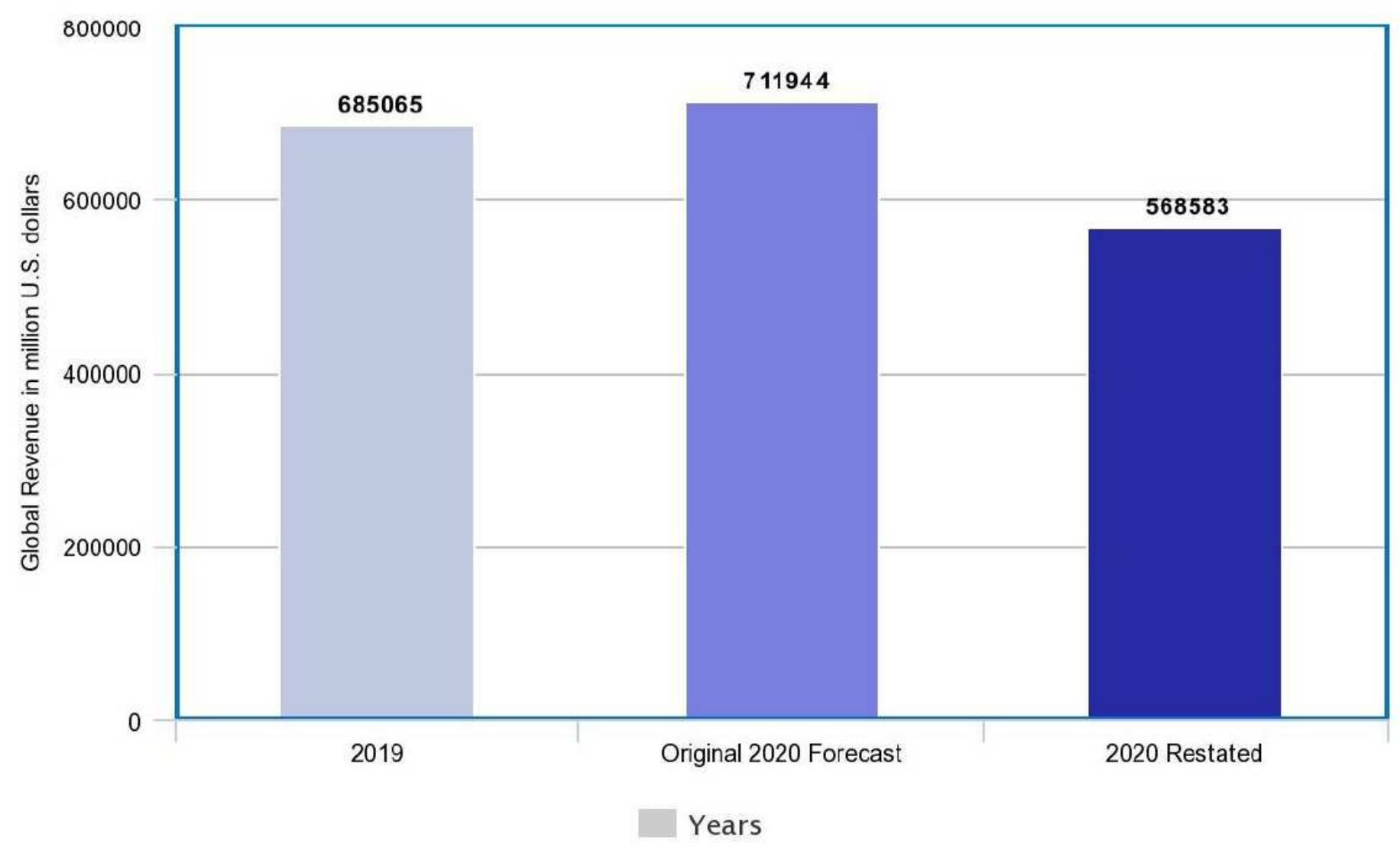

Figure 6

Graph depicting global travel and tourism revenue and the impact of COVID-19 outbreak 
Revenue of the travel and tourism industry in 2019 and the projected impact of the coronavirus (COVID-19) pandemic in 2020, by world region

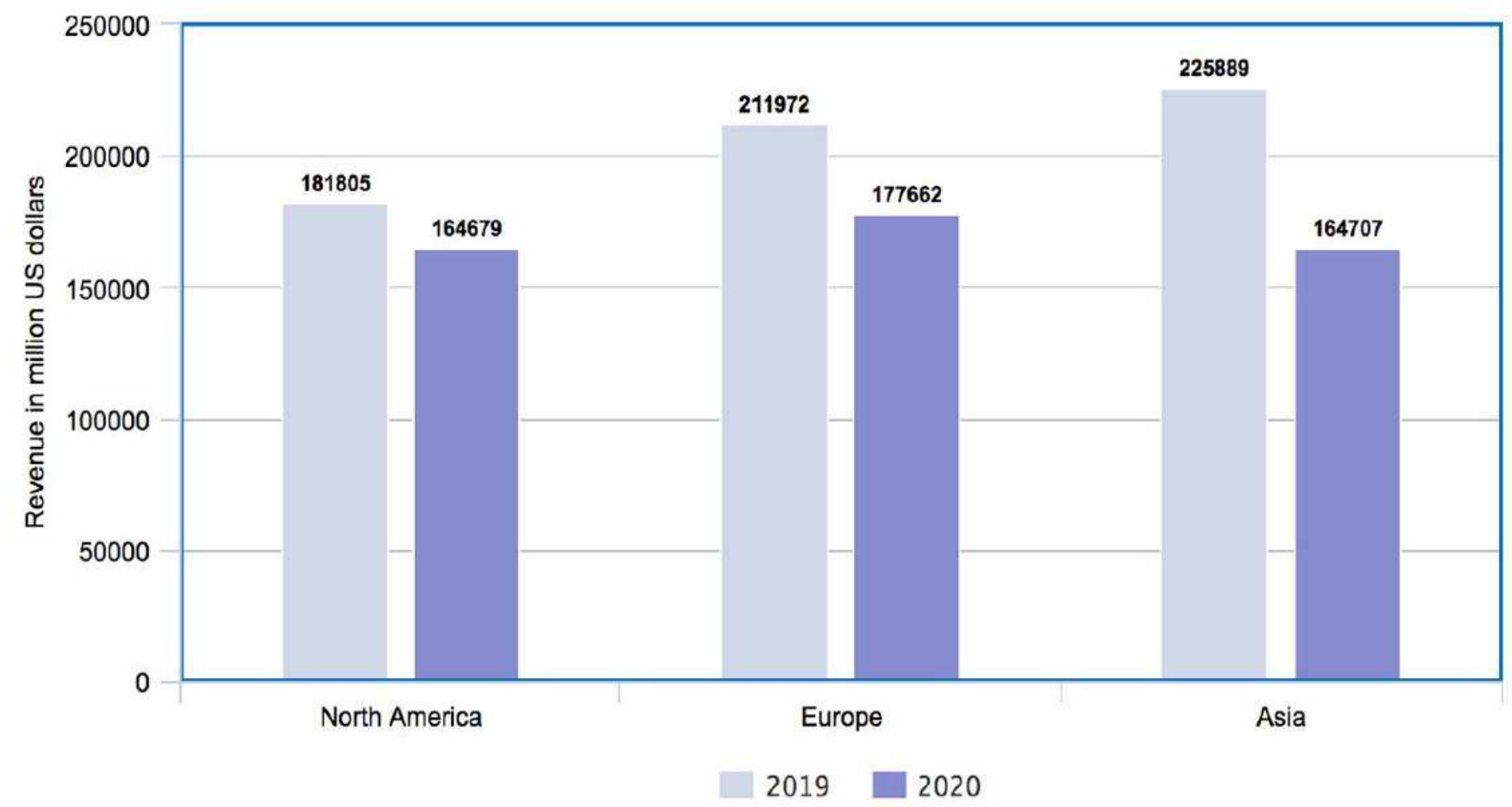

Figure 7

Graph depicting revenue of travel and tourism in 2019 and the projected impact of COVID-19 outbreak in 2020 by world region

Travel and tourism industry revenue in selected countries in 2019 and projected impact of the coronavirus (COVID-19) pandemic in 2020

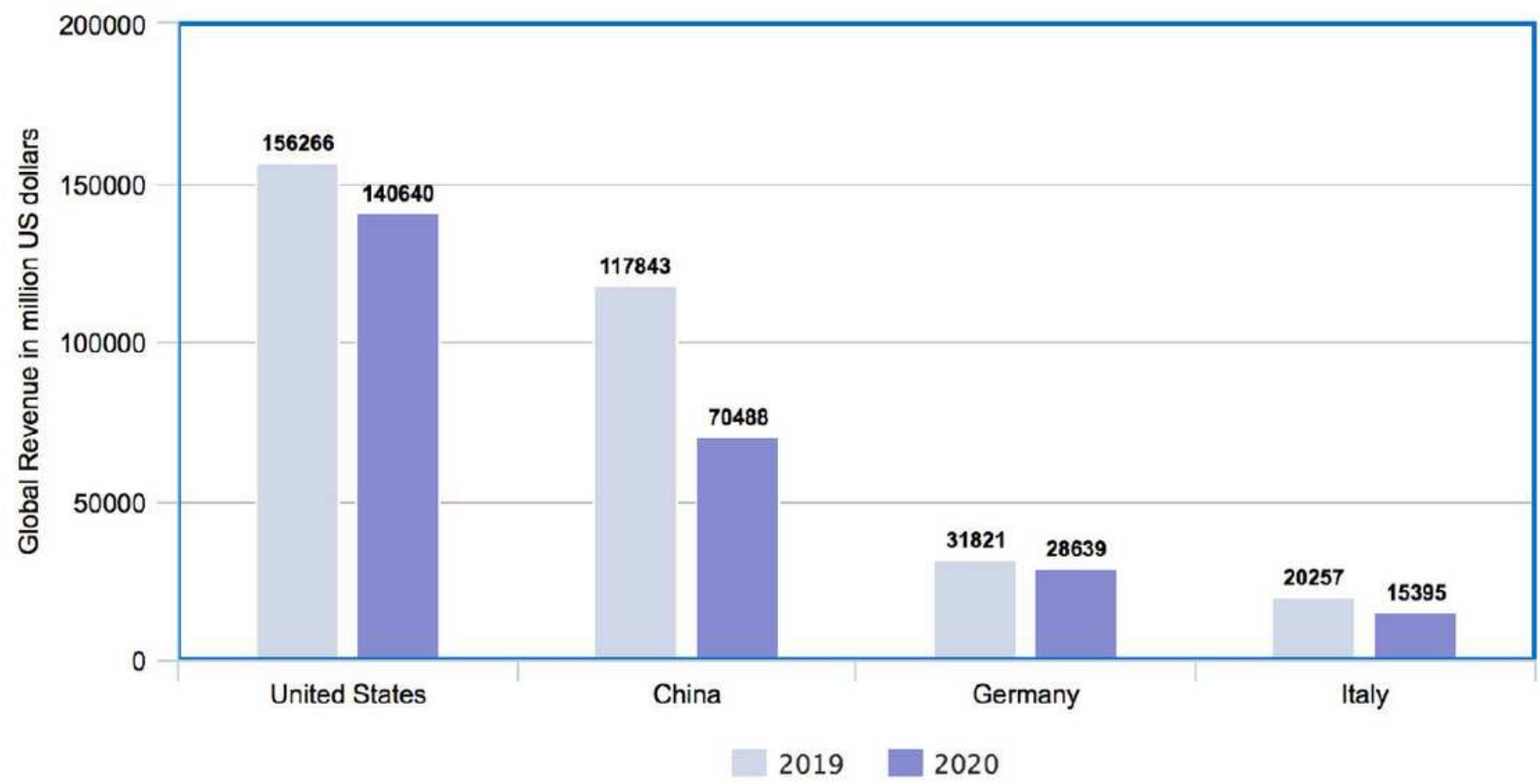

Figure 8 
Graph depicting revenue of travel and tourism in 2019 and the projected impact of COVID-19 outbreak in 2020 for specific countries

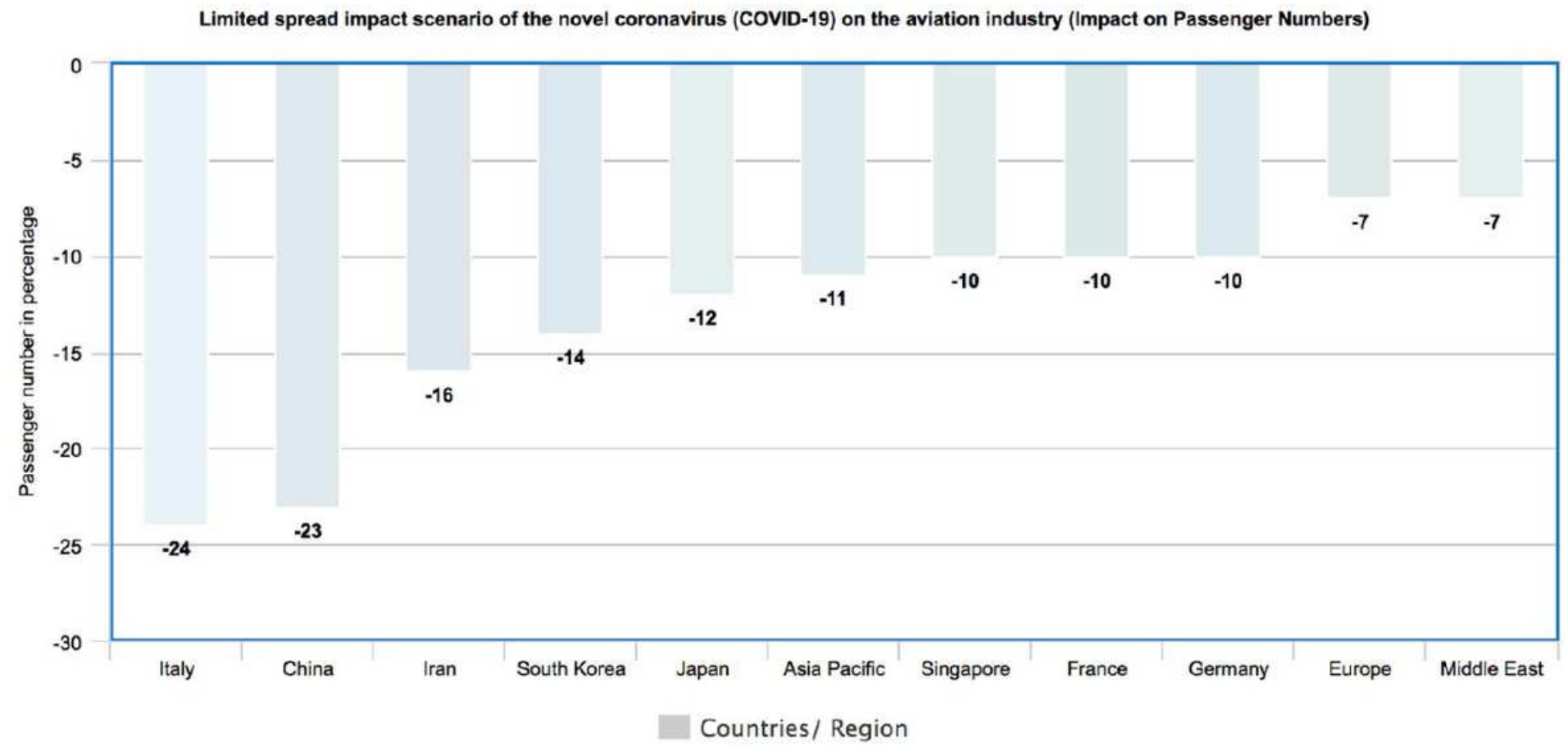

\section{Figure 9}

Graph showing limited spread impact of COVID-19 on the aviation industry for the number of passengers Fig.

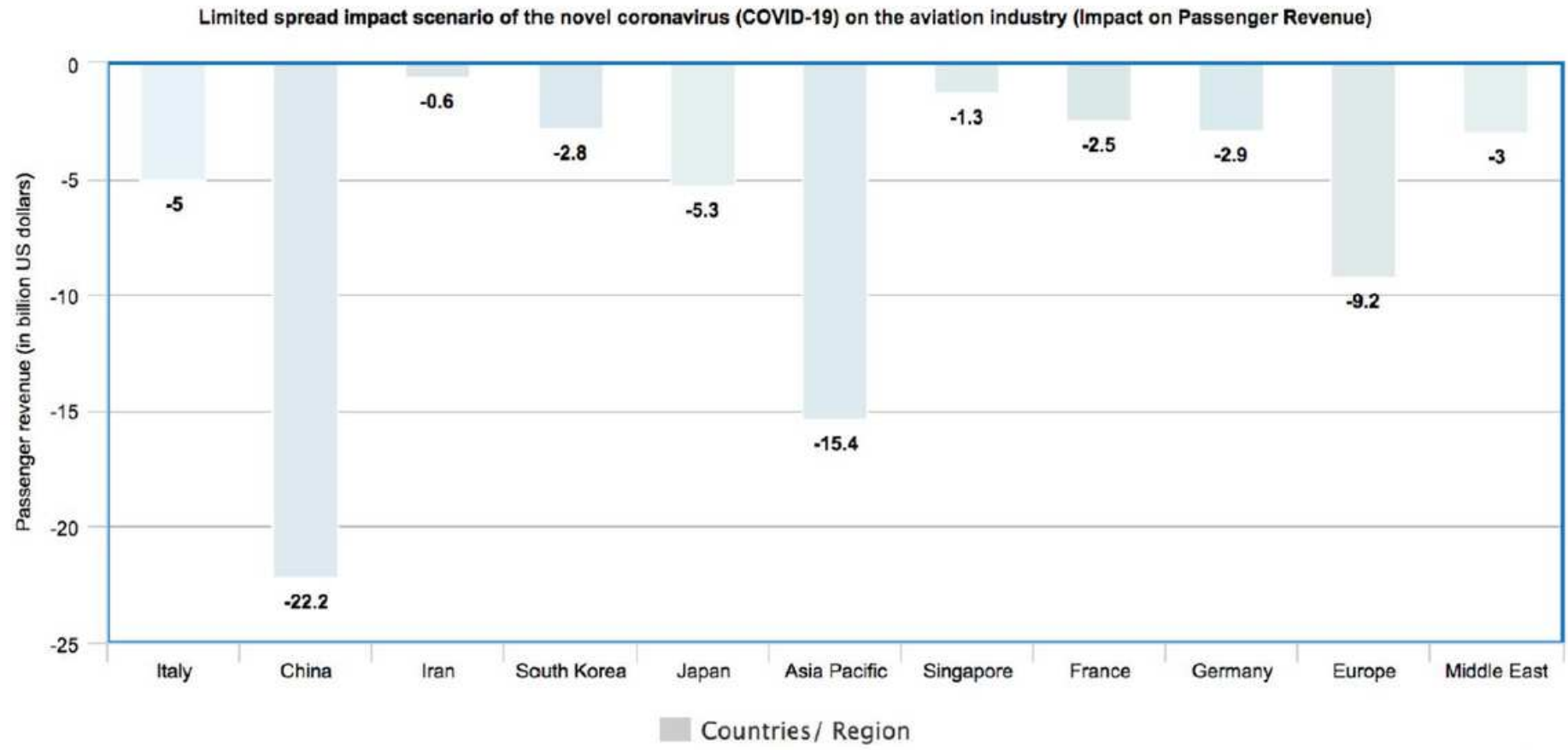

Figure 10

Graph showing limited spread impact of COVID-19 on the aviation industry for the passenger revenue 
Extensive spread impact scenario of the novel coronavirus (COVID-19) on the aviation industry (Impact on Passenger Number)

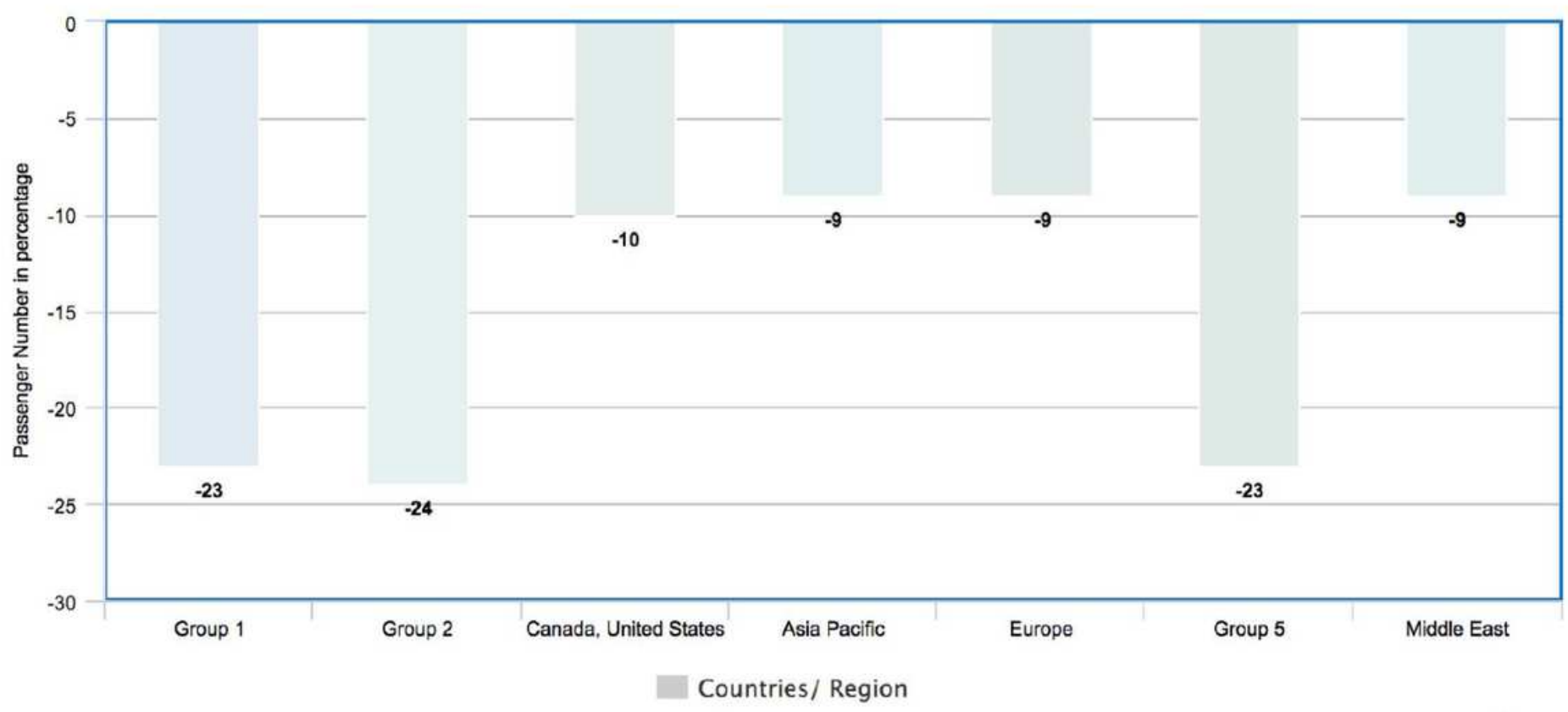

\section{Figure 11}

Graph showing extensive spread impact of COVID-19 on the aviation industry for the number of passengers

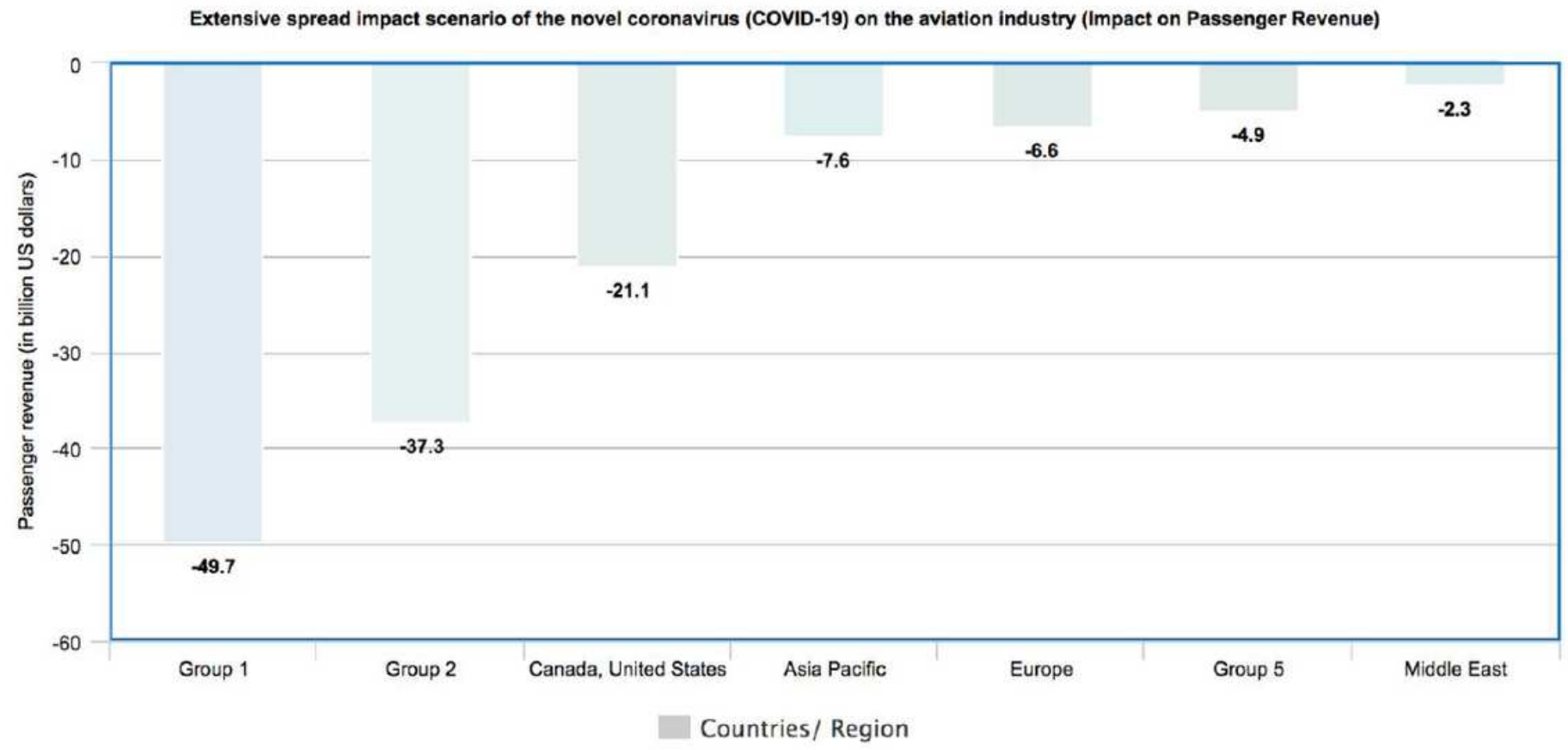

Figure 12

Graph showing extensive spread impact of COVID-19 on the aviation industry for passenger revenue 
Forecast of global high-tech product shipment impacted by COVID-19 (Coronavirus) outbreak in first quarter of 2020

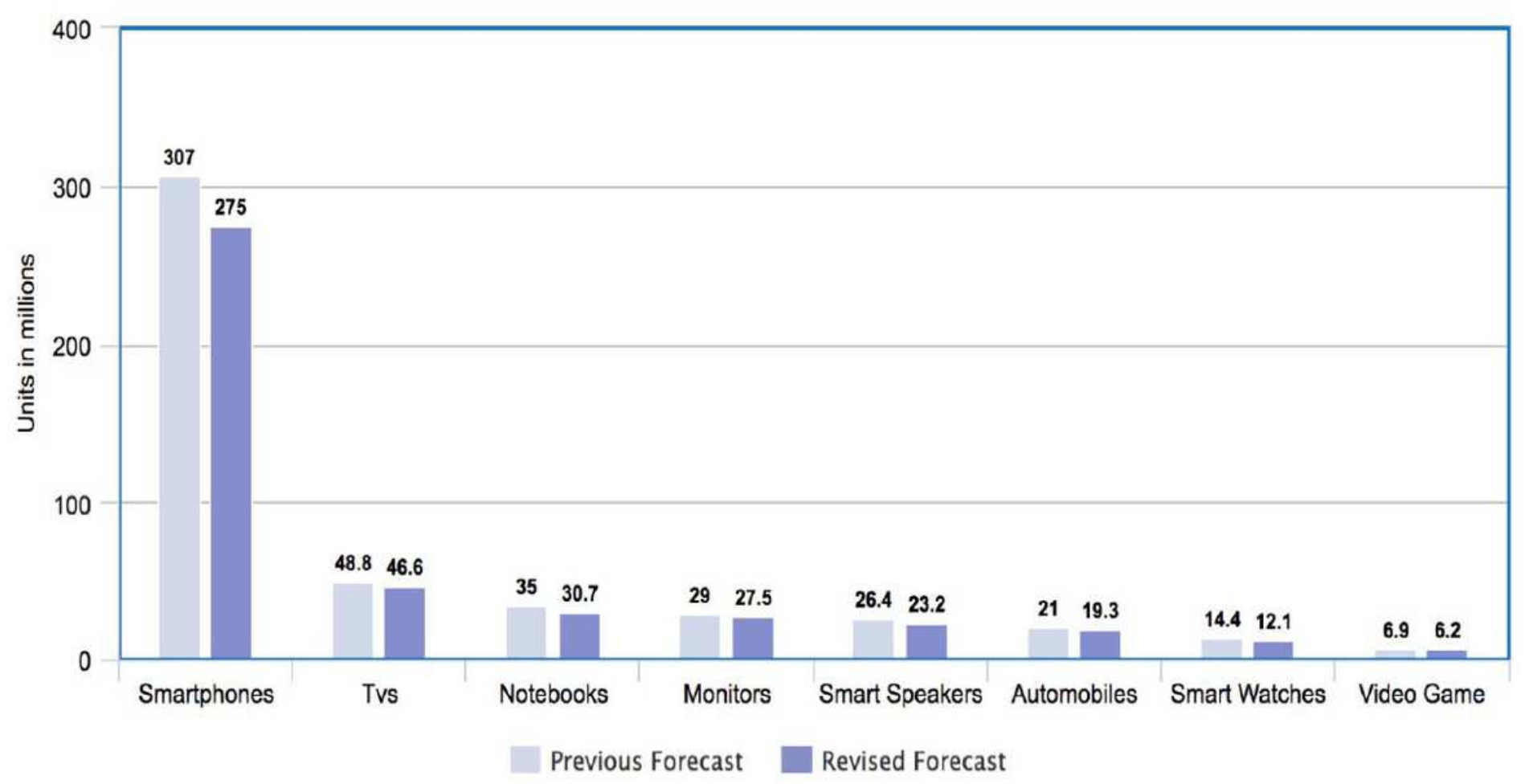

\section{Figure 13}

Graph showing a comparison of forecasts for global high tech product shipment impacted by COVID-19 outbreak 